\title{
Sultan Ahmed Külliyesi İnşâsında Yeniden Yapılan Vakıf: İbrahim Paşa Sarayı
}

\author{
The Restructured Foundation of the Sultan Ahmed Complex: \\ Ibrahim Pasha Palace
}

\begin{abstract}
Aliye ÖTEN*
Öz: Sivil mimariden, askeriye pek çok alt başlıkta değerlendirilen mimari, yapı hangi amaca hizmet ediyorsa ona yönelik en güzel imkânları sunması, kalıcı ve güzel olması ile başarıyı yakalar. 16. yüzyıl başında yapılan, geçirdiği tamirat ve yenileme faaliyetleriyle günümüze kadar gelen İbrahim Paşa Sarayı, İstanbul Atmeydanı'nda Sultan Ahmed Camii'nin tam karşısında tam bir seyir mekânı gibi tasarlanmıştır. Sarayın güzel, kalıcı ve bugün dahi Türk ve İslam Eserleri Müzesi olarak kullanılmasına imkân tanıyacak kullanışılıkta olması mimarının başarısının kanıtıdır. İlk inşası, tamir ve yenileme faaliyetleriyle asırları deviren bu güzel eserin yeri, yapımı ve kaybedilen bölümleriyle ilgili pek çok makale ve kitap yayınlanmıştır. Sarayın tarihçesi hakkındaki tartışmalarda sarayın mehterhâne, defterhâne, adliye ve diğer binalarla konum ilişkisi, geçirdiği değişiklikler ve restorasyon sınırları sorgulanmıştır. Bu konularda çok zıt fikirlerin öne sürülmesi ve değişik görüşlerin ileri sürülmeye devam edilmesi tatmin edecek kaynakların bulunmayışındandır. Buradaki kritik faktör, arşiv kaynakları ve sunduklarıdır. Sultan Ahmed Külliyesi inşası ile ilgili arşiv temelli olarak yaptı̆̆ımız araştırmalar esnasında karşılaştığımız bilgiler, bu konuda daha kesin şeyler söylemeyi kolaylaştıracak niteliktedir. Bu yüzden bu makalede öncesi ve sonrasıyla İbrahim Paşa Sarayı'nın 17. yüzyılda geçirdiği köklü değişikler, kronoloji çerçevesinde açıklanmaya çalışlacaktır.
\end{abstract}

Anahtar sözcükler: İbrahim Paşa Sarayı, XVII. Yüzyıl, Osmanlı Mimarlı̆̆, Kronoloji

Abstract: Civilian and military architecture, which are evaluated under many sub-titles, sucseeds through its ability to offer the best opportunities for it and to be lasting and beautiful if it serves the purpose. In the $16^{\text {th }}$ century the Ibrahim Pasha Palace, which was built at the beginning of the century and which has been maintained through repairs and renovation activities, was designed as a major palace directly opposite the Sultan Ahmed Mosque at Istanbul's Atmeydanı. It is proof of the success of the architect who was able to use the palace as a beautiful, permanent structure, today it is the Turkish and Islamic Works Museum. Many articles and books have been published about the palace, its construction and losses sustained to this beautiful work, which have erased over the centuries much from its first construction, through repair and renovation activities. In discussions about the history of the palace, its location related to the palace mehterhane, courthouse and other buildings, the changes and restoration boundaries are questioned. There are no satisfactory source for suggesting contradictory ideas on these matters yet different opinions are frequently suggested. The critical factor here is the archive source material. The information I have encountered in archival research on the construction of the Sultan Ahmed Kulliye will make it easier to say things more precisely in this respect. An attempt is made here to explain the fundamental changes to the Ibrahim Pasha Palace during the course of the $17^{\text {th }}$ century from this archival material.

Keywords: İbrahim Paşa Palace, 17. century, Ottoman Architecture, Chronology

\footnotetext{
*Dr. Araştırmacı, aliyeakturk@gmail.com.
} 
Çalışmaya konu olan İbrahim Paşa Sarayı'na mekânlık eden At Meydanı, İstanbul'un tarihi boyunca önemini korumuş olan en büyük meydanıdır. Bizans döneminde Ayasofya'nın güneybatısında yer alan ve araba yarışları yapılacak şekilde düzenlenmiş bulunan meydan Hippodromos (hipodrom, at koşusu alanı) adıyla anılmış ve çeşitli siyasi olaylarla bazı ayaklanmaların başladığı bir yer olarak büyük önem taşımıştır. Yapımına Roma imparatoru Septimius Severus (193-211) devrinde başlanan meydan, İstanbul'u Doğu Roma'nın başkenti ilân eden İmparator Konstantinos döneminde (324-337) tamamlatılmıştır (Gurlitt 1999, 9). Orta çizgisine Mısır'dan getirilen dikilitaş ile Delphoi Apolion Mabedi'nden getirilen Surmalı Sütun gibi ünlü anıtlar dikilen bu meydanın, "Bizans'ta Tanrı Ayasofya'ya, imparator saraya, halk da Hipodrom'a sahiptir" sözüyle vurgulanan siyasi önemi Osmanlılar zamanında da devam etmiştir. İstanbul'un fethinden sonra, ortasında Hipodrom'un bulunduğu bu meydan, At Meydanı adını alarak at yarışlarının ve cirit oyunlarının yapıldığı bir yer olarak varlığını sürdürmüştür. Ayrıca saraya yakın oluşundan dolayı değeri artarak çevresine inşa edilen önemli yapılarla yeni bir görünüm kazanmış, bayram şenlikleri ve saray düğünleriyle şehir hayatının merkezi haline gelmiştir (Cantay 1988, 82). Firuz Ağa Camii (1491), İbrahim Paşa Sarayı (16. yüzy1l), Kırkçeşme sularına ait bir sıra çukur çeşme, Üçler Namazgâhı, doğusuna Haseki Hamarnı (1553) ile ilk imar faaliyetleri gerçekleşen At Meydanı, 1617 yılında Ahmed'in inşa ettirdiği yapılar topluluğu ile tamamlanmıştır.

İbrahim Paşa Sarayı'na adını veren Makbûl (Maktul, Pargalı, Frenk) İbrahim Paşa'nın (ö. 1536/942) henüz şehzadeyken Kanuni Sultan Süleyman'ın hizmetinde bulunduğu kaynaklarda geçmektedir (Emecen 2000, 333-335). Padişaha yakınlığ sebebiyle sarayda önemli görevlerde bulunan Makbûl İbrahim Paşa, Piri Mehmed Paşa'nın azli üzerine o zamana kadarki teamüle aykırı olarak has odabaşlıktan Rumeli Beylerbeyiliğine hemen ardından da veziriazamlığa terfi etti (27 Haziran 1523/13 Şaban 929). Mısır'da mali, idari düzenlemeler yapıp asayişi sağlayan Makbûl İbrahim Paşa (1524/930), iki yıl sonra Macaristan serdarlığıyla Mohaç Savaşı'nın kazanılmasında önemli rol oynamıştır. Anadolu'daki isyanları da bastırdıktan sonra ikinci Macaristan için geniş yetkilerle donatılmış ve bu sefer de Viyana Kuşatması ile sonuçlanmıştır (1529/935). Osmanlı himayesine bir Macaristan kurulmasını sağlayan barış görüşmelerini de yürüten Makbûl İbrahim Paşa, Irakeyn seferi ile de Tebriz'e girmiş ve Bağdat'1 fethetmiştir. İftar için saraya çağrıldığ1 14-15 Mart 1536/22 Ramazan 942 gecesi hiçbir sebep gösterilmeden ansızın boğularak idam edilmiştir. Saraydan çıkarılan cesedi, Galata'da Tersane ardındaki Canfeda (Canfeza) Zaviyesi yanına "müstakil bir suffe üzerinde" defnedildi (Ayvansarayî 2001, 28). İdam sebebi hakkında kaynaklarda, saltanat hırsına kapıldığı, kazandığı kudret ve zenginliği bunu sağlamak için kullanmaya kalktığı gibi görüşler ileri sürülmüştür (Emecen 2000, 334). İbrahim Paşa'nın Kanuni Sultan Süleyman'ın kız kardeşiyle evliliği konusunda da farklı görüşler mevcuttur. Fakat kendi adıyla anılan sarayı İbrahim Paşa Sarayı, siyâsî ve askerî başarıları sayesinde padişahın iltifatına yapılan bir atıf olarak kaynaklarda yer almaktadır.

\section{Yüzyıla Kadar İbrahim Paşa Sarayı}

At Meydanı kuzey kenarında, Sultan Ahmed Camii'nin tam karşısında yer alan İbrahim Paşa Sarayı bir ayan ve kibar sarayıdır (Evliya Çelebi, Seyahâtname III, 83). 1520 Eylül-Ekim/926 Şevval'i gibi tahta çıkan Kanuni Sultan Süleyman'a Engürüs (Bulgaristan) seferi esnasında Ömer Ağa tarafından yazılan 8 Haziran 1521/2 Recep 927 tarihli bir mektupta Kap1 Ağas1 İbrahim Ağa'nın evinde yapılan değişiklikler bildirilmiştir (TSMA. D. 9621; Konyalı 1942, 7987). Sarayla ilgili ilk kayıt bu belgedir. Buna göre Divanhane yolundaki duvarın nakşedildiği; taşra (avlu) kapısından girişte ahır kapısının karşısında yer alan sofanın dört direğinin ve ahırın yenilendiği; divanhanenin iki tarafında bulunan yedi odanın tavan, sıva, ocak, pencere, dolap, 
kapı ve terasıyla birlikte tamamlandığı ve örtüsü için şeşhane kiremitlerinin beklendiği; divanhanenin has odalarının Binbirdirek'e kadar kazılıp duvarlarının inşa edildiği taşra derzlerinin vurulup, direklerinin dikildiği ve kirişlerinin yapıldığı bildirilmektedir. Ayrıca köşk, hazine odası, hamam, matbahların tamirine ve kilerle Binbirdirek tarafındaki duvara henüz başlanmadığ da ifade edilmektedir.

Diğer bir mektupta ise Kanuni'nin inşaatın durdurulmaması, gerekirse maddî ihtiyaçların hassa harçlığından karşılanması, hassa odaların üstüne bir çardak yapılması ve suyollarının yapımılla ilgili emirleri bildirilmektedir (TSMA, E. 7624; Konyalı 1942, 90-91). Bu mektupta tarih bulunmamaktadır. Birinci mektubun devamı niteliğindeki bu mektupta gerekirse hassa hazinesinin de padişahın izniyle kullanılabileceğine ilişkin bilgi oldukça önemlidir. Nitekim ceyb-i hümâyûn denilen hazinenin tahsis edilmesi padişah evkafına has bir durumdur (Sahillioğlu 1993, 465-467). Henüz evrakına rastlamasak da sonrasında saray Makbûl İbrahim Paşa'nın mülkü olmuştur.

Makbûl İbrahim Paşa'nın 1536'da idamı üzerine saray, yakınlarına tevarüs etmiştir. İlkin bir kısmı iç oğlanlarına ayrılmış, bir kısmı sadrazamlara ve diğer ileri gelenlere tahsis edilmeye başlanmıştır. 1566'da vezir, daha sonra Mısır ve Anadolu beylerbeyi olan Zal Mahmud Paşa 1574'te II. Selim'in kızı Şah Sultan'la burada evlenmiş ve 1580'de vefat edinceye kadar bu sarayda yaşamıştır. 1584'te yapı, acemi oğlanlarına ayrılan kısmı haricindeki bölümleriyle III. Murad'ın kızı Ayşe Sultan'la evlenen Sadrazam Bosnalı Damad İbrahim Paşa'ya intikal etmiştir. İbrahim Paşa'nın 1601'de ölümünün ardından malları ve sarayı, ertesi yıl Ayşe Sultan'la evlendirilen Sadrazam Yemişçi Hasan Paşa'ya tahsis edilmiştir. Ancak Hasan Paşa 1603'te katledildiğinden sadareti kısa sürmüş, saray bu defa da Ayşe Sultan'ın üçüncü eşi Güzelce Mahmud Paşa'ya geçmiştir. 1605'te Güzelce Mahmud Paşa ile Ayşe Sultan art arda vefat edince, III. Mehmed'in kızlarından biriyle evlenmiş olan Kaptan-1 Derya Damad Kara (Öküz) Mehmed Paşa'ya geçen saray (Eyice 2000, 345-346), Sultan Ahmed tarafından mevcut külliyenin yapımı için satın alınmıştır.

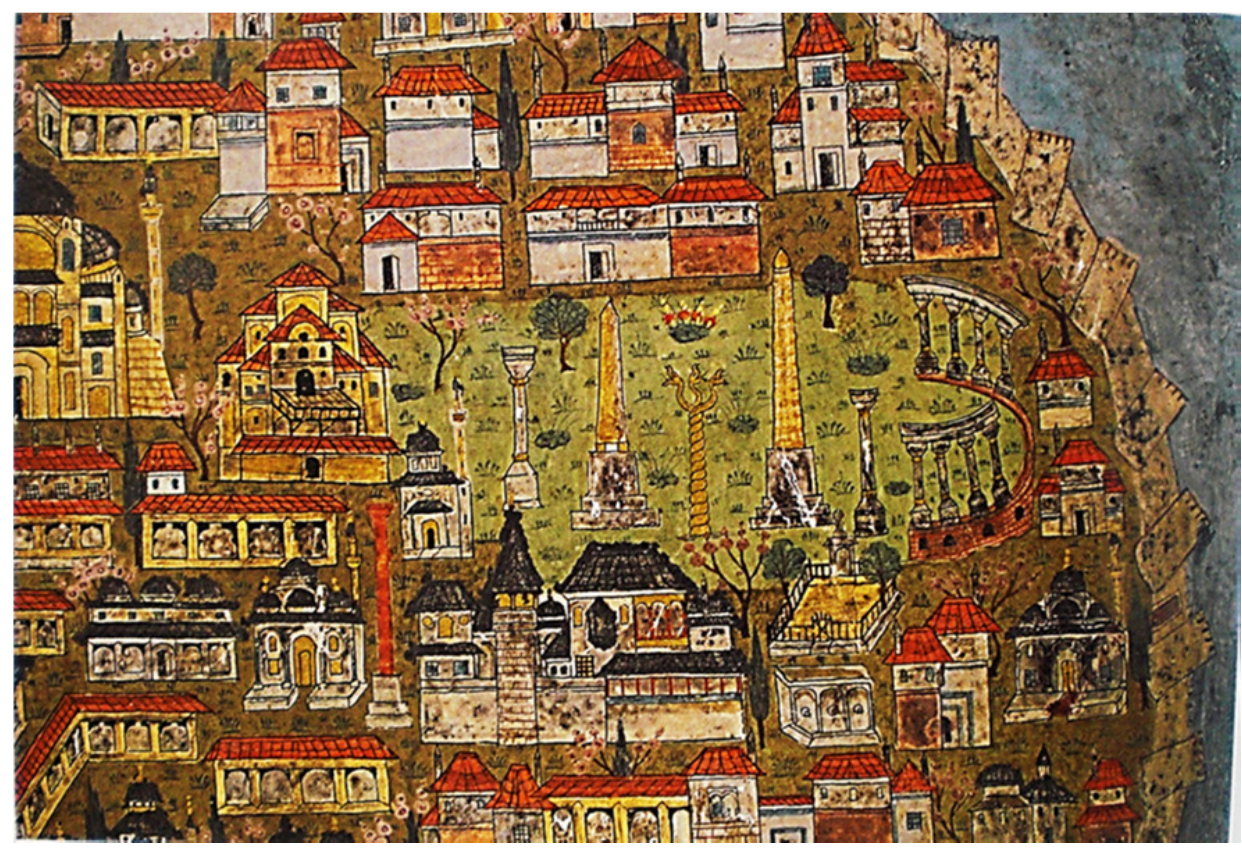

Fig. 1. Matrakçı Nasuh'un Beyân-1 Menâzil-i Sefer-i Irakeyn adlı eserindeki İstanbul Minyatürü (İstanbul Üniversitesi Kütüphanesi T.5964.8b) 
Kanuni Sultan Süleyman'ın yapımıyla yakından ilgilendiği İbrahim Paşa Sarayı, Sultan Ahmed Külliyesi inşa sürecini tanımlayan arşiv evrakında İbrahim Paşa Vakfı Sarayı olarak ifade edilmektedir. Bunun sebebi henüz bilmediğimiz bir tarihte Kanuni Sultan Süleyman'ın yaptırdığg sarayın, devlet ileri gelenlerinden Makbûl İbrahim Paşa'ya bir vesile ile verilmesidir. $\mathrm{Bu}$ eserin vakıf olması ise, Sultan Ahmed Külliyesi yapılmadan önce padişah adına satın alınıp arsaya dâhil edilmesiyle mümkün olmuştur (BOA. D. 10748.0001.00/4).

Temlik kaydına göre, Kızıl Maslak (veya musluk) yakınında İlmî Bey'in mahallesinde merhum İbrahim Paşa vakfina ait menzil, ekleri ve bahçeleriyle birlikte Ocak 1610/Zilkade 1018 tarihli belgeye göre 60.000 sikke Floriye Sultan Ahmed Han'a satılmıştır. Sultan Ahmed Külliyesi inşa sürecini gün gün anlatan Rûznamçe'de 'merhum İbrahim Paşa Vakfı Sarayı' olarak geçen bu yer, Halil bin ibn-i Abdullah mülkü ve cadde, bir tarafından Saliha Hatun ibneti Abdullah mülkü ile, Osman bin Abdullah olarak bilinen sirâc-1 hassa mülkü ile, deli kadı diye bilinen Mehmed Efendi mülkü ile, Ahmed bin Veli nâm kimse mülkü ile, el-Hac Hamza Vakfi ile, merhum kethüdâ kadın vakfı ile, bir taraftan da Mustafa Efendi ibn-i Haydaru'l-Hattab mülkü, ana yol, iç ihata duvarları ile çevrilidir (BOA. D. 10748.0001.00).

Mülknâmenin devamında “... mahdût olup dâhiliye ve hariciye muhavvatatını muhavi olup, muhavvata-i dâhiliyesi fevkani iki bab kileri ve bir müsterahı (abdest mahalli) ve bir bab küçük odasl ve bir diğer kubbeli odasl ve önünde bir dehlizi ve biribirine karşı iki bab has odalarl ve iki orta sofa ve iki yan sofayı ve bir dehliz-i kebiri ve yanında bir bab odayı ve önünde bir sofa ve müsterahı bir tahta purşu (?) denmekle meşhude olup hariciye ve dâhiliye adidey-i muhteviye muhavvatasını haviye olup bir tarafi merhum Ebussuud Efendi bağçesi ve bir tarafi derya ve iki tarafi tarik-i am ile mahdut olup padişah-ı müşerun ileyh..." ifadeleri ile tarif edilir. Böylece iki kapılı kileri, abdesthanesi, bir küçük odası, kubbeli odası, önünde dehliziyle karşılıklı iki has oda, iki orta sofa, bir büyük dehliz ve yanında bir odası, sofası, abdest mahalli ve diğer birimleriyle büyük bir yapı anlatılmaktadır.

1610 yılına ait bu bilgiler, sarayın o günkü durumunu net bir şekilde ortaya koymaktan uzaktır. Kanuni Sultan Süleyman'a mektupla verilen malumatın içeriği daha detaylıdır. Bu mektuplarda sarayın divanhanesi, dört direk üstünde yükselen sofas1, divanhane önünde yedi odas1, has odaları, köşkü, hazine odası, hamamı, matbah1, kileri ve has odalar üstüne yapılması planlanan çardaklar geçer. Aradan geçen yaklaşık bir asırlık zaman diliminde İbrahim Paşa Sarayı, birtakım değişiklikler geçirmiştir. Ünlü Osmanlı tarihçisi Solakzâde, At Meydanı Sarayı adında bir yapıdan bahseder (Atasoy 2012, 51). Fakat At Meydanı etrafında 16. yüzyıl itibarıyla Ahmed Paşa Sarayı (Semiz Ahmed Paşa Saray1- Derviş Paşa Saray1- Ayşe Sultan Kasrı) ve Mehmed Paşa Sarayı (Mesih Paşa Sarayı, Sokollu Mehmed Paşa Sarayı), İskender Paşa Sarayı gibi büyük saraylar olduğu evrak kayıtlarında geçmektedir (BOA. D. 35/178-194, BOA. D. 10748.0001.00). Hangisinin At Meydanı Sarayı olarak tarif edildiğini tespit etmek bu nedenle zordur. İbrahim Paşa Sarayı'nın ilk imarında mimarı ve tam inşa tarihi bilinmese de, geçirdiği müdahaleler hakkında birtakım bilgiler mevcuttur.

Buna göre matbah, kiler, zemin ve üst kat odaları, ağa odaları, meydan ve kapı sundurmaları, at binaları, helvahanesi, fırını, hamamı ve kasırlarıyla birlikte 17. yüzyıl başında yıkımından hemen önce büyük bir saray konumundayken; ilk evraklardan farklı olarak helvahâne ve firın bir asırlık süreçte saray bünyesine eklenmiştir. Mimarbaşı Koca Sinan'ın 1538 itibariyle göreve geldiği düşünülecek olursa; sarayın ilk inşasında onun rolü olmadığı açıktır. Ancak, 1582 Mayıs ayında Şehzade Mehmed'in sünnet düğünü için yapılan hazırlıklar bünyesinde, sarayın kapısı, merdiveni değiştirilmiş; kasr-1 şahnışin yapılmış ve bu bölümün önüne de merasime davetliler için üç katlı ahşap localı tribünler inşa edilmiştir (Atasoy 2012, 60). Bu süreçte firın ve 
helvahane de eklenmiş olmalıdır. Mimar Sinan'ın görevde kaldığı son altı yıla tekabül eden bu inşa faaliyetinde; sadece bu yapıların onun eliyle yapılmış olabileceği düşünülebilir. Nitekim Tezkiretü'l-bünyan'da “At Meydanı Sarayı tecdiden bina olundu” şeklinde bir ifade de mevcuttur (Sai Çelebi 1988, 42).

İbrahim Paşa Sarayı'nın mehterhâne, adliye ve hapishâne gibi önemli yapılar arasındaki tam konumu, vakıf olması gibi meselelerin açıklığa kavuştuğu ve saray bünyesindeki değişikliklerin en iyi okunabileceği dönem, eldeki arşiv kayıtlarının verdiği bilgiler çerçevesinde 17. yüzyıl başıdır. Sultan Ahmed Külliyesi inşa evrakı bünyesinde yeniden ele alınan bu güzel yapının durumu kronolojiyle birlikte bir sonraki bölümde yer almaktadır.

\section{Sultan Ahmed Külliyesi İnşâsında İbrahim Paşa Sarayı'nın Yeniden Yapılma Süreci}

Sultan Ahmed Külliyesi yapım aşamasında, Sultan Ahmed Han'ın bu büyük evkafı için, civardaki diğer araziler de değerlendirilmiştir. Bu yüzden bu külliyenin inşasında çok büyük bir alan elden geçirilmiş ve yeni bir şehircilik anlayışı çerçevesinde, tamir ve yeniden yapım faaliyetleri de gerçekleştirilmiştir. Kuşkusuz Sultan Ahmed Külliyesi imâret, eğitim ve gelir yapıları göz önünde bulundurulduğunda çok büyük bir alana yayılmış vaziyettedir. Bizans'ın olduğu kadar Osmanlı İstanbulu'nun da merkezi olarak planlanan bu alan; çevre binaların uyumu da gözetilerek son halini alacak biçimde mükemmelen şekillendirilmiştir.

Kızıl Maslak (veya musluk) yakınında İlmî Bey'in mahallesinde merhum İbrahim Paşa vakfına ait menzil, ekleri ve bahçeleriyle birlikte Ocak 1610/Zilkade 1018 tarihli belgeye göre 60.000 sikke Floriye Sultan Ahmed Han'a satılmıştır (BOA. D.10748.0001.00/4). Bu tarihten sonra yoğun bir yıkım faaliyetine başlanmış ve gerekli değişiklikler için alan kazanılmıştır. 15 Haziran 1610/23 Rebîu'l-evvel 1019 tarihi itibariyle İbrahim Paşa Vakfı Sarayı'ndaki yıkılan yerler ve karşıllı̆ında verilen ücretler inşa evrakında detaylı bir şekilde yer almaktadır (BOA. D. 35/20). Hassa Mimarbaşı Mehmed Ağa marifetiyle İbrahim Paşa sarayındaki at binaları, alt kat ve üst kat odalar, helvahâne, firın ve kilerin yıkım ücreti, 974 zirâ' karaçav için 3.896 Akçe, 3.400 zirâ' duvar için 6.800 Akçe, 532 zirâ' eski duvarlar için 1.064 Akçe, 913 zirâ' elvâh döşemeler için 1.834 Akçe, 750 zirâ' bilinen bazı yerler için 1500 Akçe, 1400 zirâ' furuş için 2.800 Akçe, 1.100 zirâ' odaların duvarları için 2.200 Akçe, 318 zirâ' karaçav için 654 Akçe, 570 zirâ' döşeme için 1.140 Akçe olmak üzere toplam 21.878 Akçe ilgililere ödeme yapıldığ 1 görülür. Buna göre at binaları, alt ve üst kat odalar, helvahâne, firın ve kiler yıkılmıştır.

16 Eylül 1610/27 Cemâziye'l-âhire 1019 tarihindeki inşa faaliyetlerini ele alan Rûznâmçe'ye göre, Mimar ağa tezkiresiyle yıkılan yerler yıkım işini yapan usta ve yıkım ücreti gibi detaylarıyla birlikte yer almaktadır. Mimar ağa tezkiresine göre Vinito Kalfa eliyle İbrahim Paşa Sarayı'nda matbah, odalar, kiler, tahtacı, kilerci, musandra ve sâireye kadar zemin ve üst kat odaları yıkım ücreti 7.200 Akçe, mi'mâr ağa tezkiresine göre Mavridis Kalfa eliyle İbrahim Paşa Sarayı meydan sundurması, kapılar sundurmaları, ağalar odaları, oda ve karaçav (mesned) yıkım üstâdları ücreti 6.977 Akçe'dir (BOA. D. 35/29). Buna göre matbah, kiler, musandra, zemin ve üst kat odaları, meydan ve kapı sundurmaları ve ağalar odaları yıkılmıştır.

2 Ağustos 1609/1 Cemâziyelevvel 1018- 13 Ekim 1617/12 Şevval 1026 tarihleri arasında şekillenen Sultan Ahmed Külliyesi inşasında; İbrahim Paşa Sarayı'nın önce dış duvarları yıkılmış, arsa ve bodrum katları atölyeler için kiralanmıştır. Daha sonra at binaları, alt kat ve üst kat odalar, helvahâne, firın, kiler, kasırlar ve hamamı yıkılan saray, ihtiyaca göre yeniden yapılmıştır (bk. kronoloji). Bu süreci en iyi şekilde tanımlayabilmek için kronoloji kısmına yer verilmiştir. $\mathrm{Bu}$ aşamada kenifleriyle birlikte bir kasrın yapıldığ kiralanmaya devam edildiği ve hamamın büyütülüp havuzla birlikte tamamlandığı görülür. 
İbrahim Paşa Sarayı'nın yeri konusundaki tartışmalar At Meydanı ve Mehterhâne ile konum ilişkisi çerçevesinde gelişmektedir. 17. yüzyıl itibariyle bu yapıların konumu hakkında Sultan Ahmed Külliyesi'nin inşa evraklarında birtakım bilgiler mevcuttur. Sultan Ahmed Camii mihrap önündeki alan Kabasakal Mahallesi olarak tanımlanmıştır. Buradaki Sokollu Mehmed Paşa Sarayı, hamamı hariç yıkılmıştır (BOA. D.00211.0001.00). Ayrıca temlik kayıtlarına bakıldığında; camiin güneybatı köşesinde bulunan "mescid-i kanlu"nun nakkaşhâne ve arslanhâne bitişiğinde olduğu ve haymenin de burada bulunduğu belirtilmektedir (BOA. D. 35/13-16-40-90-159-169). Hayme, mehter çadırının karş11ığı olarak kullanılmış olmalıdır. İnşâ süreci boyunca organizasyonun daimi üyeleri arasında yer alan hayme görevlisine nafaka ödenmiştir. Bu kayıtlardan birinde Kanlu Mescidi'ndeki hayme ve sakalara (3 nefer, iki aylık 480 Akçe'lik) ödeme yapıldığı bildirilmektedir (BOA. D. 35/163).

Yine temlik kayıtlarında Sokollu Mehmed Paşa Sarayının yer tanımlaması şöyle yapılmaktadır. "Dârü's-Saltanatü's-Seniyye Kostantîniyyetü'l-Mahmiyye mahallâtından Kabasakal, Sinan Ă̆a mahallesinde vâki' (Kabasakal'in Sultanahmed'de Ayasofya civarinda olduğu belirtiliyor) üç tarafi tarîk-i 'âm ve bir tarafi merhûm İskender Paşa türbesine ve 'Abdi Ă̆g evleri ile mahdûd olup mahavvatayni müştemil olup muhavvata-i dahiliyyesi Sultan kapusu yanında bir maltacılar odasını ve bir kapucular odasını ve üstünde altl ve üstlü kapu ağası odasını ve bir büyük ve bir küçük ağalar odasını ve keniflerini ve önünde çeşmeyi ve bir hoca odasını ve bir kilârı ve dîvânhâneyi ve biri birine karşı kâş̧ili iki büyük odaları ve orta suffesini ve fiskiyeyi ve mukabelesinde bir büyük havzı (havuz) ve köşkü ve sadefkârî pencereli ve halkârî musandiralı bir kaftan odasını ve içi şadırvan havuzlu 14 arabî pencereli ve bir sedefkârî dolaplı 8 terekli ve 2 şahnişinli bir kubbeli kâşî odayl (rengârenk fayanslarla kaplı oda) ve üstünde kâş̧îli bir kubbeli köşkü ve kâşîli has bir mükemmel hamamı ve dolapları ve kapısı halkârî kâş̧̂li bir kış odasını ve yanında kâşîli bir mükellef çilehâneli ve bir büyük dâir odasını ve bir büyük dîvânhâneyi dahi ve bir kethüdâ odasını ve üstünde bir köşkü ve 5 mükemmel odalarl ve önünde dehlizi ve 2 yan suffeli kilârı ve 6 zîr zeminli bir hazine odasinı ve 3 halvetli 6 kurnalı havuzlu ve büyük odunluğu ve 4 kıta bahçeyi ve içinde bir havuz ve kurşun kubbeli bir köşkü ... ve âhır-ı havlıda vâkl' 4 hastalar odasını ve çeşmeyi ve 2 firınlı bir matbahı hâvî olup muhavvata-i hâriciyyesi bir büyük dîvânhâneyi ve yaninda bir arz odasını ve dîvânhâneye muttasıl biri birine karşı iki odayı has odayl ve bir orta suffeyi ve iki dehlizi ve bir .... ve abdesthâneyi ve önünde bahçeyi ve şadırvanı ve halkârî ve sadefkârî 5 pencereli ve dolaplı kâşîli bir büyük odalı ve şehnişinli halkârî ve sadefkârî 5 pencereli ve bir kapılı bir büyük odayı dahi ve yaninda içeri girecek dehliz ve 2 mükellef hamam ve abdesthâne ve müsterâhı ve bir büyük hazinedâr başı odasinı ve abdesthâne ve kenifi ve karşısında bir odayı dahi ve altlı ve üstlü tûlânî bir büyük nöbetçiler odasını ve bir büyük iç oğlanları odasını ve bir büyük iç oğlanları muallimhânesini ve önünde iç oğlanları meydanını ve bir büyük altlı üstlü hazine odasını ve câmeşûy -hâneyi (çamaşırlık) ve bir kârgîr kütük mahzenini ve bir mehter -hâneyi ve 2 sarrâc odasını ve bir dehlizi ve bir câmeşûy-hâneyi dahi ve kapu üstünde bir kethüdâ odasinı ve yanında bir hazîne odasını ve bir nöbetçi çavuşlar odasını ve abdesthâneyi ve cebehâne ve 37 aded çaşnigîr odalarını ve altında 4 büyük tayfa (tâife) ahurunu ve tahminen 1500 araba otluk olur zîr-i zemîni ve bir büyük mahzeni ve biri birine karşı iki has ahırl ve içinde bir kapu önünde bir çeşmeyi ve kuyumcular kârhânesini ve bir büyük kapıcıla odasını ve meydanı ve şadırvanı ve bir büyük firın anbarını ve 3 firını ve içinde akar suyu ve tekneleri ile ve üstünde bir büyük odayl ve fevkânî tûlen 40 zira' arzen 12 zira' terziler kârhânesini ve 6 ahır ve helvâhâne ve 4 un anbarını ve fevkânî 9 bab kilerciler odasını ve bir büyük akar sulu matbahı ve 11 aded aşçllar odasını ve çeşme ve kenifi muhteviye olup"babam merhûm-ı mezbûr Mehmed Paşadan” (söz konusu Mehmed Paşa meşhur Sokollu Mehmed Paşa'dır ve Sadrazamlık süresi kesintisiz 14 yıldır (1565-1579), irs-i şer'î ile (verâset yolu ile) 
intikal edip "Mehmed Paşa Sarayı demekle marûf olan mülk-i mevrûsumu" içinde cârî olan 2.5 mülk suyu ile 60.000 sikke Floriye Saadetlü Pâdişâh-ı Âlempenâh hazretlerine (bey'-u bât-i sahîh$i$ şer'î ile bey') ve vekîl-i mûmâ ileyhe teslim edip vekîl-i mûmâ ileyh hazretleri dahî müvekkilleri seadetlü padişah hazretleri içün iş̧irâ ve tesellüm eyledikten semen-i merkûm 60.000 sikke Florinin 30.000 tâmmü'l-vezin ve kâmilü'l-ayâr florisini vekil-i müşârun ileyh hazretleri yedinden ahz u kabz edip bâkî kalan 30.000 sikke florisini "Medine-i Ebû Eyyûb el-Ensârî kazasina tâbi" Sütlüce nâm mevzide vâki' merhum İbrahim Paşa bahçesi" demekle ma'rûf olup büŷtt-i müteaddideyi hâvî hâriciye ve dâhiliye muhavvateyni müstemile olup bir cânibi Handan Ağa bahçesi ile derya ve bir canibi merhûme Ayşe Sultan hazretleri vakfettikleri bahçe ile Camiye gidecek tarîk-i âm ve bir tarafi merhum İbrahim Paşa'nın vakfettiği şem 'hâne ve bakkal dükkanı ve berber dükkanı ve kahvehâne ve bir tarafi tarik-ı âm ile mahdûde olup ve yine hadika-i mezbûre civarında merhûm İbrahim Paşa'nın hazînedârı hadîkası demekle meşhûre olup hâriciye ve dâhiliye büyût-ı adîdeye muhteviye muhavveteyni hâviye olup bir tarafi merhum "Ebu's-Su'ûd Efendi bahçesi" ve bir tarafi deryâ ve iki tarafi tarîk-ı 'âm ile mahdûde olup Padişâh-ı müşârun ileyh hazretlerinin silk-i mülklerinde münharıt (haritası çizilmiş) olan hadîkalarını pâdişah hazretleri 30.000 sikke-i haseneye "bana bey' u teslim ettikten sonra" semeni olan 30.000 sikke Flori zimmetimde deyn olmuş idi. Sarây-ı sâlifü'l-beyân semeninden bâkî kalan 30.000 sikke Flori ... semen-i merkûm 60.000 sikke Flori bi'l-temâm bana vasll olmuş olup ba'de'l-yevm zikr olunan hadîkalar benim mülküm olup" Sarây-ı mezkûr" (konu edilen Sokollu Mehmed Paşa Sarayı) Saadetlü Padişah hazretlerinin mülk-i müşterâlarıdır, keyfe mâ-yeşâü ve mâ-yürîd mutasarrıf olalar dedikte "makarr-ı mûmâ ileyh İbrahim Paşa hazretlerinin" ikrâr-l meşrûhu vekîl-i

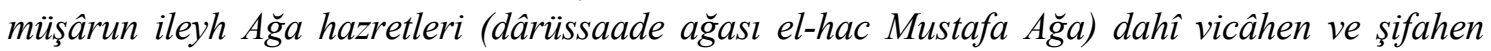
tasdîk u tahkîk ettikte mâ-hüve'l-vâkl' alâ vukû'ihî gable'l-talep ketb olundu. Tahrîren evâhir-i cumâde'l-ûlâ min şuhûr-i sene semâniye 'aşere ve elf, 1018 (Tarih, 1609 Eylül sonlar1/1018 Cemâziye'l-evvel sonlar1/) (TSMA. D.10748; Mustafa Lütfi Bilge 2013, 525-557).

Bu kayıtta Mehmet Paşa Sarayı'nın bölümlerinden biri de mehterhâne olarak zikredilmektedir. Vezir ve kibar saraylarında da mehter birimlerinin olduğu göz önünde bulundurulacak olursa; bu sarayla ilgili yapının bizim aradığımız mehterhâne olmadığı anlaşılacaktır (Özcan 2003, 547-549) Bunun yanında Mescid-i Kanlu yakınında olarak zikredilen mehterhânenin de tam yeri bilinmemektedir.

İbrahim Paşa Sarayı'nın yakınında, hatta önünde olduğu belirtilen mehterhâne yapısı hakkında bilgi ise İbrahim Paşa Sarayı'nın yeniden yapımını ele alan kayıtların arasında değil de, hiç beklenmedik bir yerde geçmektedir. Bu kayıtta, At Meydanı'ndaki mîrî mehterhânenin yakınında olarak tarif edilen horasan dükkânları kaplaması için neccârlara verilen 10.000 Akçe ustalık ücreti zikredilmektedir (BOA. D. 35/22) Bu yapıdan İbrahim Paşa Sarayı yenileme faaliyeti boyunca bir daha bahsedilmemiştir. Günümüzde Türk ve İslam Eserleri Müzesi olarak faaliyet gösteren yapı Sultan Ahmed Külliyesi inşa evrakında bahsi geçen kasır olduğuna göre; mehterhâneye bu süreçte hiç müdahale edilmediği anlaşılacaktır. Bu da İbrahim Paşa Sarayı'nın 17. yüzyıl itibariyle At Meydanı'na bitişik, bugünkü konumunda olduğu ve mîrî mehterhânenin de At Meydanı'nda bulunduğu anlamına gelmektedir.

Nitekim mehterhâne ile ilgili son Osmanlı vak'anüvislerinden Ahmet Lütfi Efendi, Tarih-i Lütfi adlı eserinde de "1870 (h. 1287)'e kadar Osmanl Devleti'nde mahkûmlar, Tersane-i Amire'de kürek cezasına çarptırlliyordu. Sultan Abdülaziz'in zamanında eski mehterhâne kalıcı ve geçici mahkûmlar için iki daire olacak, hastane, hamam, cami, klise vb mekânları bulunacak şekilde tamir edilerek umûmî hapishane haline getirilmiştir" şeklinde bilgi vermektedir (Öten 2008, 69). 


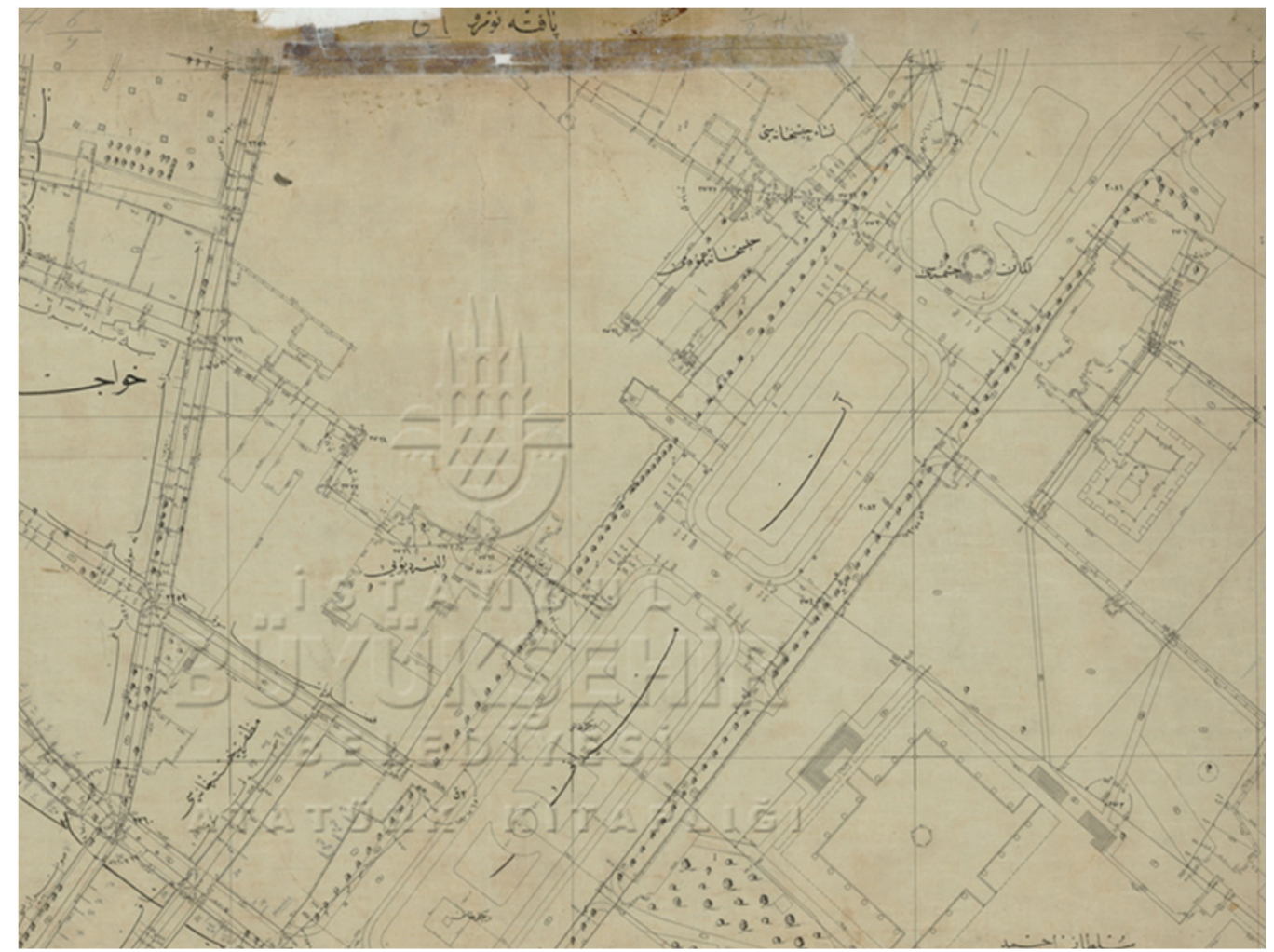

Fig. 2. Sultan Ahmed Meydanı'nda 1914 yılı İbrahim Paşa Sarayı ve etrafındaki yapıların durumu (İ.B.B. Atatürk Kitaplığı Hrt_Gec_001169)

Buna göre 1870 yılına kadar kullanılan mehterhâne bu tarihten sonra umumî hapishane olarak kullanılmaya başlanmıştır. Bu yapının Mescid-i Kanlu yakınında tarif edilen mehterhâne kasrı değil de çadır mehterhânesi (mehterân-1 hayme) olması akla daha yatkındır (Çürük 1993, 165-166). 17. yüzyıl konumuyla ilgili kesin bilgi olmasa da bu mehterhâne yapısının sonraki yüzyıllardaki durumu hakkındaki bilgiler sonraki bölümde daha geniş çerçevede ele alınacaktır.

1611'de saray, I. Ahmed'in kızı Gevherhan Sultan'la evli Kaptan-1 Derya Topal Receb Paşa'ya verilmiştir. Uzun süre Receb Paşa'nın adıyla anılan saray, 1632'de sadrazam olan paşanın aynı yıl IV. Murad'ın emriyle katledilmesi üzerine bu padişahın silahtarı Mustafa Ağa'ya temlik edilmiştir. IV. Murad 1640'ta ölünce saray, Sultan İbrahim'in en gözde musahibi olan Silahdar Yusuf Paşa'ya verilmiştir. 1645'te padişahın üç yaşındaki kızı Fatma Sultan'la nikâhlanan Yusuf Paşa düğünden bir y1l sonra idam edilmiştir. Saray, bu defa Fatma Sultan'la evlendirilen bir diğer padişah musahibi Damad Fazlı (Fazlullah) Paşa'ya verilmişse de bunların sarayda yaşamadıkları Fazlı Paşa'nın İstanbul dışı görevlerle merkezden uzaklaştırıldığı bilinmektedir. Sarayı 1648'de Sultan İbrahim'in, Telli Haseki adıyla tanınan gözdesine hediye ettiği de anlaşılmaktadır. Bundan sonra XVII. yüzyıl boyunca sarayın sadrazamlar kaptan-1 deryalar ya da beylerbeyi gibi bürokrasinin en yüksek üyeleri ve hanedana damat olan devlet ricaline tahsisi devam etmiştir. Evliya Çelebi (Seyahatname III, 257) yapının İstanbul'daki vezir saraylarının en büyügü olduğunu kaydetmektedir. Saray Kasım 1652/Zilhicce 1062'de yanmış, 1720'ye doğru Nevşehirli Damad İbrahim Paşa tarafından tamir ettirilmiş veya yeni bir bina yaptırılmışsa da 1741/1154'te tekrar yanması üzerine artık bir daha onarılmamıştır. 1675'teki depremde harap olduğu anlaşılan sarayın XVII. yüzyılın son çeyreğine girerken Köprülüzade Fazıl Ahmed Paşa tarafından kapatıldığına dair bir kayıt da bulunmaktadır (Eyice 2000, 345-347). 


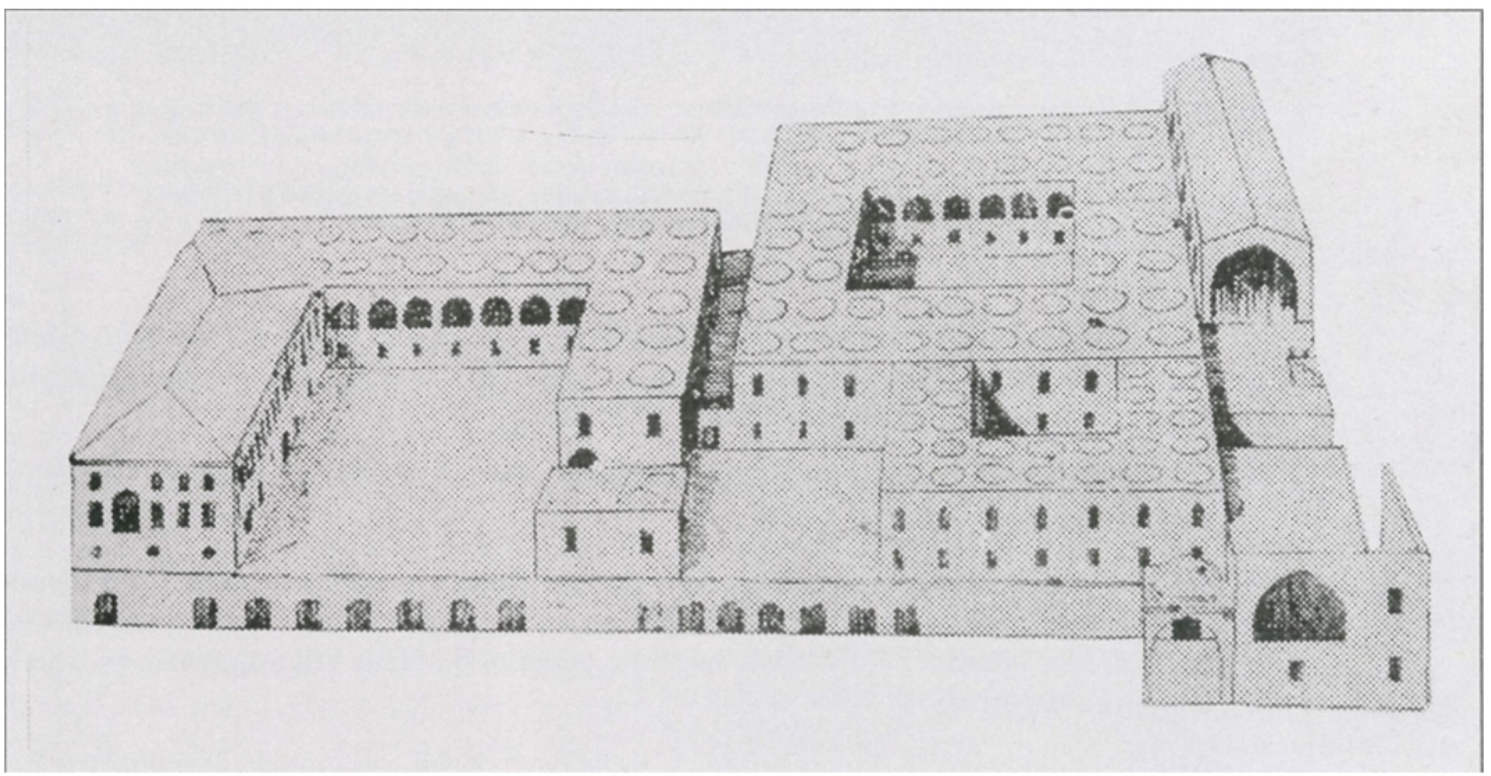

Fig. 3. İbrahim Paşa Sarayı'nın Mimar Sedat Çetintaş tarafından çizilmiş kuşbakışı görünümü (Atasoy 2012, 111)

İbrahim Paşa Sarayı'nın kenifleriyle birlikte kasrının yapıldığı, aynı dönemde zeminindeki odaların Sultan Ahmed Külliyesi inşasında gerekli malzemelerin teminini sağlayan atölyeler için kiralanmaya devam edildiği ve hamamın büyütülüp havuzla birlikte tamamlandığı süreç yıkım ve yapım aşamalarını içeren detaylarıyla kronolojik bir şekilde aşağıda ifade edilmiştir.

6 Eylül 1609/6 Cemaziyelâhire 1018 Cumartesi

- Hassa Mimarbaşı Mehmed Ağa marifetiyle merhum İbrahim Paşa vakfı sarayının yıkımı için rrgatlara kesilen 40.000 Akçe ücret masrafi- (BOA. D.35/4).

-Malum Mehmed Ağa marifetiyle satrancî hesapla 1.518 Zirâ' 3.400 Akçe’ye merhum İbrahim Paşa Vakfı Sarayı duvarları yıkılması için kazı ücreti-.

10 Ekim 1609/11 Receb 1018 Cumartesi

El-masraf - Müfettiş Mevlânâ Ali Efendi hücceti gereği, mütevelli Mehmed Bevvâb eliyle Cami'i Şerîf mevzî' inde İstanbul'da merhum İbrahim Paşa Vakfı Sarayı muaccele (peşin) kirası için 40.000 Akçe- (BOA. D.35/5).

- Mevlânâ (Ali Efendi) hücceti gereği Cami-i şerîf tarafındaki halen yapımı devam eden hazîne için mirahor-1 sânî eliyle masrafları karşılanmaya devam edilen Câmi-i şerîf önündeki merhum İbrahim Paşa Sarayı'nın tamir ihtiyaçlarına 20.000 Akçe kıymet-.

-1018 Cemâziye'l-evvelinden Recep sonuna kadar üç aylık günlüğü 30.5 Akçe'den toplam 3.240 Akçe merhum İbrahim Paşa Vakfı Sarayı kirâ pahası-.

12 Ekim 1609/13 Receb 1018 Pazar

-Masraf- Piri eliyle İbrahim Paşa Sarayı kasr-1 hümâyûnu kenîfi (tuvaletleri) için Kıyyesi 48.5'ten 388 Akçe kurşun parası ve Mehmed Halife eliyle büyük tabanların ücreti 1.500 Akçe, Toplam 28.604 Akçe- (BOA. D.35/5b).

\section{Ekim 1609/25 Receb 1018 Cumartesi}

Masraf -Hassa Mimarbaşı Mehmed Ağa marifetiyle kesilen Koca Yani eliyle İbrahim Paşa sarayı kasr-1 hümâyûnu kaplaması için neccârlara harcanan 6.600 Akçe kıymet ücret- (BOA. 
D.35/6).

2 Kasım 1609/4 Şa'ban 1018 Pazartesi

-Mi’mar Ağa marifetiyle kesilen Merhum İbrahim Paşa vakfının yıkılan sarayından toprak taşıyan götürücü kazıcılara 10.000 Akçe ücret- (BOA. D.35/7).

16 Aralık 1609/19 Ramazân 1018 Çarşamba

Masraf- Şaban başından Ramazan sonuna kadar yevmiye 36 Akçe'den toplam 2.160 Akçe Cami-i Şerif mevkiine katılan merhum İbrahim Paşa vakfi için verilen kira ücreti- (BOA. D.35/10).

\section{Ocak 1610/9 Şevvâl 1018 Salı}

Masraf -Yazıcı zımmî eliyle İbrahim Paşa sarayındaki hamam için 114 adet 13 Akçe'den toplam 1.482 Akçe pınar ücreti, Bab-1 hîmeden bina-yı şerîfe pınar getirilmesi için 19 Hıml, 4 Akçe'den toplam 76 Akçe hammaliye ücreti- (BOA. D.35/11).

6 Ocak 1610/10 Şevvâl 1018 Çarşamba

El-masraf- Hassa Mimarbaşı Mehmed Ağa marifetiyle İbrahim Paşa sarayındaki hamam suyoluna 250 Zirâ' 30 Akçe'den toplam 7.500 Akçe'ye künk çıkarılması, Galata'dan makara dili getirmek için 30 Akçe hammaliye ücreti, hamam için suyolcu ve mermercilere 120 Akçe ücret, 1018 Ramazan boyunca kâtibin defterine göre 256 nefere 76.846 Akçe neccâr ücreti, 1018 Ramazan boyunca neccâr kâtibi defteri gereğince 28 nefere 6.048 Akçe sengtraş ücreti, aynı dönem için neccâr kâtibi müfredat defteri gereğince 238 nefere 12.718 Akçe 1rgat ücreti, 1018 Ramazan boyunca 4 nefer errekeşâna 84 gün için 1.680 Akçe ücret-.

30 0cak 1610/5 Zilka‘de 1018 Pazar

El-masraf -1018 yılı Zilkade başından 1019 Muharrem ayı sonuna kadar Anadolu ve Rumeli'den emr-i şerîf ile getirilen neccâr ve sengtraşlara eşlik eden ve aynı zamanda Dergâh-1 Âlî bevvâb1 4 nefere 120 gün üzerinden 3.600 Akçe nafaka; Mustafa nâmlı şahsa yevmiye 30, Ali nâmlı şahsa yevmiye 30, Mehmed bin Hüseyin nâm şahsa yevmiye 30, Hasan bin Abdullah nâm şahsa yevmiye 30,1018 Zilhicce ortasında el-müfettiş ve el-müverrâh Mevlânâ Ali Efendi hücceti gereği bina-i şerîf emîni Kalender Efendi eliyle İbrahim Paşa Sarayı hamamının külhanı (cehennemlik) için elinde olan ve yine bilinen vakıf tarafından kefil olarak İskender Paşa Vakfi'ndan Hasan bin Hüseyin'den 3000 Akçe peşin kira, 1018 Şevvâl'i için mutemet Mehmed'e 240 Akçe kıymetinde nafaka- (BOA. D.35/13).

26 Şubat 1610/2 Zilhicce 1018 Cuma

Masraf -İbrahim Paşa sarayı hamam dolabı rahtına 380 Akçe ücret- (BOA. D.35/13).

27 Şubat 1610/3 Zilhicce 1018 Cumartesi

-Masraf; Hacı Hüseyin eliyle İbrahim Paşa sarayı hamamı için kantarda 167 adet, 36 lodura, 308 Akçe'den 51.546 Akçe sürb (kurşun) levhalar pahası, yeniçerilerden Ahmed eliyle kantar 3, 38 lodura 947 Akçe'den toplam 4.200 Akçe alet başı pahası, Menteş Yahudi eliyle 10 adet kıyyesinde 30, 18 Akçe'den toplam 540 Akçe demir varyesi pahası, Hacı Hüseyin eliyle Tahta'l-kal'a'dan binaya 54 kıyye, 4 Akçe'den 216 Akçe'ye sürb (kurşun) taşıma ücreti, mimar ağa marifetiyle Hüseyin eliyle sürb (kurşun) levhaların taşınması için 600 Akçe kurşuncu ücreti, İbrahim Paşa sarayı hamamının kaplaması için 3.000 Akçe mermer yontucu ücreti-.

21 Mart 1610/25 Zilhicce 1018 Pazar

-Hassa Mimarbaşı Mehmed Ağa marifetiyle Koca Yani eliyle bina-i şerifin eksilen mühimmatı, mermerciler kârhanesi ve sundurma ile İbrahim Paşa sarayı yeni hamamı camekânı 
kaplaması için neccârlara 26.300 Akçe kıymetinde ücret ödenmesi- (BOA. D.35/14).

29 Mart 1610/4 Muharrem 1019 Sal1

El-masraf - 1018 Şevval başından Zilhicce sonuna kadar üç ay cami-i şerif mevkiine dâhil edilen merhum İbrahim Paşa vakfı için günlüğu 11 Akçe'den üç aylık toplam 990 Akçe kira ücreti- (BOA. D.35/14).

\section{Nisan 1610/8 Muharrem 1019 Cumartesi}

-Masraf- Mimarbaşı Mehmed Ağa marifetiyle İbrahim Paşa Sarayı'ndan zer-dûzân (altın işlemeli) odalarının yıkımı için Dimitri ve Karakaş'ın lağımcılarına verilen 15.604 Akçe ücret, kârgîr duvarlar için 3.204 Akçe, siyah duvarlar için 2.804 Akçe, karaçav (duvarcı iskelesi veya duvar desteği) yıkımı için 9.756 Akçe, mimarbaşı Mehmed Ağa marifetiyle İbrahim Paşa Sarayı hamamı yapımı için hamamcı Yani’ye 3.000 Akçe ücret, İbrahim Paşa Sarayı'nın mezbûr hamamına ocak ve külhan yapımı için Yorgi’ye 3.000 Akçe ücret- (BOA. D.35/15).

3 Nisan 1610/9 Muharrem 1019 Pazar

-140 Akçe nukrâ levhaları pahası, 2.400 Akçe İbrahim Paşa sarayından kasr-1 hümâyûn için mor ve kırmızı çuka pahası-.

6 Nisan 1610/12 Muharrem 1019 Çarşamba

-Masraf- 72 Akçe İbrahim Paşa Sarayındaki hamam külhanı için beyza pahası- (Kıymet 72).

14 Nisan 1610/20 Muharrem 1019 Perşembe

-Masraf- İbrahim Paşa Sarayından hamam kapısı için 0.5 kıyyelik 50 Akçe kıymetinde sülûgen pahası, bahsi geçen hamam için 2 kile 40 Akçe kıymetinde alçı pahası, bahsi geçen hamam kazısı için 50 Akçe mum pahası- (BOA. D.35/16).

16 Nisan 1610/22 Muharrem 1019 Cumartesi

-Masraf - İbrahim Paşa Sarayı'ndaki kenîfler (tuvaletler) için 3 adet 280 Akçe kıymetinde kullaplı köşebend demiri pahası-.

3 Mayıs 1610/9 Safer 1019 Pazartesi

- 1018 Zilkade başından 1019 Muharrem sonuna kadar 1 nefere günlügü 5 Akçe'den üç ay için toplam 450 Akçe İbrahim Paşa sarayı şakirtleri haremi nafakası- (BOA. D.35/16).

9 Mayis 1610/15 Safer 1019 Pazar

-Piri eliyle İbrahim Paşa Sarayı hamamı cüzleri çıkarılması için 1.096 Akçe ücret, 2.5 kıyye 370 Akçe kıymetinde çengâr (yeşil boya), 160 Akçe kıymetinde seng-i rastık, 120 Akçe kıymetinde mürdeseng (kurşun oksit, mavimtırak renk), 2 kıyye 36 Akçe kıymetinde lök, 2 kıyye 30 Akçe kıymetinde çam sakızı, 80 Akçe kıymetinde sarı zırnık, 60 Akçe kıymetinde kara akma, 100 Akçe kıymetinde kazan ve 20 Akçe kıymetinde tas, hammaliye ücretiyle birlikte 40 Akçe'ye testi ücreti, 80 Akçe kıymetinde tuz- (BOA. D.35/17).

18 May1s 1610/24 Safer 1019 Salı

-Hassa Mimarbaşı marifetiyle İbrahim Paşa sarayındaki hamam için 2.299 Akçe kıymetinde zikredilenlerin pahası; 1.039 Akçe kıymetinde şem'-i revgân, badana için 1.260 Akçe- (BOA. D.35/17).

19 Mayıs 1610/25 Safer 1019 Çarşamba

-Masraf- Kâbil Bey eliyle İbrahim Paşa Sarayı hamamı için nühâs (bakır) lüleler (28 Adet, 20 si yeni, 8'i tamirden 600 Akçe'lik lüleler), Kavak İskelesi'nden İstanbul'a ateştaşı ve seng-i 
taban taşıyan Hacı Yusuf sefinesine 2.240 Akçe navlun ücreti, Ahmed Paşa Sarayı'ndan büyük ağaçların çıkarılması zamanı kesilen 320 Akçe kıymette iki baş ganem (küçükbaş hayvan), Ali ve diğerleri eliyle köhne (eski) mesâmiri (çivileri) 1slah etmek için kıptî demircilere 3.267 Akçe, Kavak İskelesi'nden İstanbul'a ateştaşı getirmek için peremeci (kayıkçı) Sarı Yusuf'a 2.800 Akçe ücret, yekûn 15.520 Akçe- (BOA. D.35/18).

26 Mayıs 1610/3 Rebîu'l-evvel 1019 Çarşamba

-Masraf - Hassa Mimarbaş1 Mehmed Ağa tezkiresine göre tahmin üzere kesilen 22.200 Akçe kıymetinde İbrahim Paşa sarayındaki hamamın camekân içinde, tobhâ, yuvarlak sofası, kurnaları, zand taşı, eski döşemeleri, büyük ve küçük sofaların etrâfı, yeni kâse, küfeke döşemeleri, kapı nukraları ve diğer işler için mermertraşlık ustalık bedeli- (BOA. D.35/18).

3 Haziran 1610/11 Rebîu'l-evvel 1019 Perşembe

-Hassa Mimarbaşı Mehmed Ağa marifetiyle suyolcu İbrahim ve üstâd Mehmed eliyle İbrahim Paşa sarayı hamamı suyolu ve ihtiyaçları masrafları, bezir yağı, kireç, horasan, sürb (kurşun), ustalık ve irgatlığıyla tüm suyolu 388 zirâ', 960 künk temeli, sarayın dış bahçesi için 40 adet künk olmak üzere toplam 1.000 adet künk 25 Akçe'den toplam 25.000 Akçe ücreti-.

15 Haziran 1610/23 Rebîu'l-evvel 1019 Salı

-Masraf - Hassa Mimarbaşı Mehmed Ağa tezkiresine göre ustalık ücretleri, hamam ustaları için kesilen 6.500 Akçe kıymetinde ücret, hamam söveleri için 2.000 Akçe, 36 çuval 70 Akçe'den toplam 780 Akçe kıymetinde ahger (demir), kapı için 80 Akçe kıymetinde kufl. Hassa Mimarbaşı Mehmed Ağa tezkiresine göre yıkım için lağımcılara ödenen ücret; 1.982 zirâ' siyah duvarların yıkımı için 3.964 Akçe, 1.296 zirâ' kârgîr duvarların yıkımı için 3.588 Akçe, 2.861 zirâ' karaçav oda yıkımı için 11.444 Akçe, kirişlemeyle birlikte 487 zirâ' elvâh döşemelerin yıkımı için 974 Akçe, 333 zirâ' döşeme duvarı yıkımı için 666 Akçe, içerideki 60 zirâ' kerpiçlerin yıkımı için 120 Akçe omak üzere toplam 20.756 Akçe- (BOA. D.35/20).

-Hassa Mimarbaşı Mehmed Ağa marifetiyle İbrahim Paşa sarayındaki At binaları, alt kat ve üst kat odalar, helvahâne, firın ve kilerin yıkım ücreti, 974 zirâ' Karaçav 3.896 Akçe, 3.400 zirâ' duvar 6.800 Akçe, 532 zirâ' eski duvarlar 1.064 Akçe, 913 zirâ' elvâh döşemeler 1.834 Akçe, 750 zirâ' bilinen 1500 Akçe, 1400 zirâ' furuş 2.800 Akçe, 1.100 zirâ' odaların duvarları 2.200 Akçe, 318 zirâ' karaçav 654 Akçe, 570 zirâ' döşeme 1.140 Akçe olmak üzere toplam 21.878 Akçe-.

\section{Haziran 1610/29 Rebîu'l-evvel 1019 Pazartesi}

-Masraf - İbrahim Paşa sarayı vakfı kirası kalanı için 1019 Muharrem başından Rebiu'levvel sonuna kadarki 1.170 Akçe kıymet- (BOA. D.35/20).

9 Temmuz 1610/17 Rebîu'l-âhire 1019 Cuma

-Masraf- (Mimarbaşı) Mehmed Ağa marifetiyle pâdişâh-1 âlempenâh yolunda İbrahim Paşa Sarayında karaçav ve duvar neccârlarına 2.588 Akçe ücret, Mehmed kâtip defterine göre 455 nefer neccâra 156.862 Akçe ödeme, kâtibe göre 431 nefer seng-traşana 180.486 Akçe ücret, müfredât defterine göre 3 nefer gündelikçi ahengerlere (demirci) 1.012 Akçe ücret, Ahmed Bâşe eliyle çarûb için kova pahası 160 Akçe.

-Masraf- Bahsi geçen Mehmed Ağa marifetiyle Padişah-1 Âlempenâh yolundan İbrahim Paşa Sarayı'nda karaçav ve duvar neccarları için 2.588 Akçe ücret- (BOA. D.35/22).

27 Temmuz 1610/6 Cemâziye'l-evvel 1019 Salı

-Masraf- mimar ağa tezkiresine göre su haznesi kapısı ve hammâm kapısı, külhan ve 
hammâm mevkiinin belirlenmesini sağlayan yıkımlar için 1.200 Akçe üstâdlar ücreti-.

-Hassa Mimarbaşı Mehmed Ağa marifetiyle Nakkâş Hasan Çelebi eliyle İbrahim Paşa Sarayı'nın kasr-1 hümâyûn'unun iki kere nakş-kerden (kalemişi) süslemesi için nakkaşlara 14.000 Akçe ücret-.

28 Temmuz 1610/7 Cemâziye'l-evvel 1019 Çarşamba

-Murad eliyle İbrahim Paşa sarayındaki kasr-1 hümâyûn pencereleri kafeslerinin 500 Akçe pahas1-.

10 Ağustos 1610/20 Cemâziye'l-evvel 1019 Salı

-Masraf - İbrahim Paşa Sarayındaki hamamın kaplanmasında bazı emirlerin 787 Akçe pahası, Mehmed eliyle İbrahim Paşa Sarayı için 20 adet 7 Akçe'den toplam 140 Akçe ham fette pahası, İbrahim Paşa Sarayı için 90 Akçe çarup pahası- (BOA. D.35/24).

12 Ağustos 1610/22 Cemâziye'l-evvel 1019 Perşembe

-İbrahim Paşa sarayı için 34 adet 340 Akçe sandık bakiyesi-.

17 Ağustos 1610/27 Cemâziye'l-evvel 1019 Salı

-Kabil Bey eliyle İbrahim Paşa sarayı havuzu ve hamamı için 6.000 Akçe değerinde lüleler(BOA. D.35/24).

19 Ağustos 1610/29 Cemâziye'l-evvel 1019 Perşembe

-Masraf - Mimar Ağa tezkiresine göre Hacı Hüseyin eliyle İbrahim Paşa Sarayı'ndaki merdiven çatısı ve kasr-1 hümâyûn örtüsü için kurşun levhalara 900 Akçe kurşuncular ücreti(Kiymet 900).

-Hassa Mimarbaşı Mehmed Ağa marifetiyle kasr-1 hümâyûn'un yapımında İbrahim Paşa Sarayı'nın tamir edilen yerleri için alçı pahası, sırça ve billûr camlar üstâdlarına 3.860 Akçe ücreti, 100 çeki 3.500 Akçe alçı, 20 çeki kâşî (çini) 700 Akçe pahası, 2.400 adet, üstâdlarının 4.800 Akçe ücreti, toplam 12.860 Akçe-.

-Hassa Mimarbaşı Mehmed Ağa marifetiyle İbrahim Paşa sarayının 1000 Akçe kafalar kaplama ücreti, Sancil eliyle İbrahim Paşa Sarayı hamamı için 200 adet 4000 Akçe sebu badana pahas1-.

21 Ağustos 1610/1 Cemâziye'l-âhire 1019 Cumartesi

-Masraf - Dimitri eliyle İbrahim Paşa Sarayı külhanhanesi için 300 adet 360 Sahh tuğla-i çarşûy-1 harcî, Kumkapı'dan bunların binaya taşınması için 14 Akçe hammaliye ücreti- (BOA. D.35/25).

22 Ağustos 1610/2 Cemâziye'l-âhire 1019 Pazar

-Masraf - İbrahim Paşa sarayı kasr-1 hümâyûnu için 600 Akçe kafeslerin kaplanması ücreti, İbrahim Paşa sarayı kenifleri (tuvaletleri) döşemesi için 6 zirâ' 1.440 Akçe kıymetinde kırmızı hokka-.

23 Ağustos 1610/3 Cemâziye'l-âhire 1019 Pazartesi

-Masraf - İbrahim Paşa sarayındaki kazı için 340 Akçe tamir ücreti-.

29 Ağustos 1610/6 Cemâziye'l-âhire 1019 Perşembe

-İbrahim Paşa sarayında kasr-1 hümâyûn kafesleri örtüsü için 500 Akçe destâr pahası-.

7 Eylül 1610/18 Cemâziye'l-âhire 1019 Salı 
-Hassa Mimarbaşı Mehmed Ağa tezkiresi marifetiyle suyolcular Ahmed ve İbrahim eliyle İbrahim Paşa sarayında 966 Akçe suyolu masrafi, suyolcular için 900 Akçe masraf- (BOA. D.35/28).

16 Eylül 1610/27 Cemâziye'l-âhire 1019 Perşembe

-Mimar ağa tezkiresine göre Vinito Kalfa eliyle İbrahim Paşa Sarayı'nda matbah, odalar, kiler; tahtacı, kilerci, musandra ve sâireye kadar zemin ve üst kat odalar 7.200 Akçe yıkım ücreti, mi'mâr ağa tezkiresine göre Mavridis Kalfa eliyle İbrahim Paşa Sarayı meydan sundurması, kapılar sundurmaları, ağalar odaları, oda ve karaçav (mesned) yıkım üstâdları ücreti 6.977 Akçe, mimar ağa tezkiresine göre Lâğımcı Karakaş eliyle Mehmed Paşa Sarayı'nda duvar ve araba koymak için sundurma duvarı, set, sofa, küfeke taşından yonma duvar, karaçav (mesned), kemer araları kapıları duvarları ve döşeme ve matbah ve firın ve duvarların 17.124 Akçe yıkım ücreti, mi'mâr ağa tezkiresine göre Lâğımcı Karakaş eliyle sofalar, küfeke taşından yonma kemerler ve kemer kapıları, ağalar odaları, kâgir mektep duvarları yıkımı için 4.866 Akçe ücret- (BOA. D.35/29).

10 Ekim 1610/22 Receb 1019 Pazar

-İbrahim Paşa sarayında kazı için 2.040 Akçe kapak taşı pahası, Manol eliyle 68 zirâ' 812 Akçe, Serhoş eliyle 68 zirâ' 816 Akçe, Şirin eliyle 34 zirâ' 408 Akçe- (BOA. D.35/34).

12 Ekim 1610/24 Receb 1019 Sal1

-Masraf - 1019 Rebîu'l-âhire başından Cemâziye'l-âhire sonuna kadar İbrahim Paşa vakfı sarayının 960 Akçe kira küsurat1-.

25 Aralık 1610/9 Şevvâl 1019 Pazartesi

-Masraf- 1019 Şevvâl başından 1020 Muharrem sonuna kadar 3.600 Akçe çeşitli mismârlar (Ensiz çivi, mıh, demir kazık) için Samakov'dan getirmek üzere Sinan'a 3.600 Akçe nafaka, Mimarbaşı Mehmed Ağa marifetiyle İbrahim Paşa Sarayı etrafından (inşa sahasından) toprak tahliyesi için 6.000 Akçe lağımcı ücreti- (BOA. D.35/42).

-Hassa Mimarbaşı Mehmed Ağa marifetiyle Ali Koca, Karakaş ve Mıhtar eliyle sahrıc taşları, ev duvarları ve alçak pâyelerin yıkımı için lağımcı ücreti.

25 Ocak 1611/11 Zilkade 1019 Çarşamba

-Mimar Ağa marifetiyle Piri eliyle İbrahim Paşa sarayında pâdişâh-1 âlempenâh iskemlesi için 1500 Akçe mutallâ raht pahası- (BOA. D.35/46).

3 Şubat 1611/20 Zilkade 1019 Çarşamba

-Masraf - İbrahim Paşa sarayında mutfak yıkımında kurban için 640 Akçe kıymete 4 baş küçükbaş hayvan pahası-.

15 Mart 1611/30 Zilhicce 1019 Sal1

-1 Rebîu'l-âhire-30 Zilhicce 1019 tarihleri arasında 9 ay 11 gün süreyle 2.970 Akçe'ye merhum İbrahim Paşa Vakfı Sarayı'nın icaresinden kalan küsur, bahsi geçen sarayın 1.000 Akçe battâliye(?) ücreti, toplam 3.790 Akçe ücret- (BOA. D.35/48).

-Menteş Yahudi eliyle vardiyacıbaşı, seng-trâşlar ve neccârlar kalfası için 14.400 Akçe mor kofa pahası, hâlen yapımı devâm eden İbrahim Paşa Sarayı kasr-1 hümâyûnu kalemişleri yapımında çalışan nakkâş̧ların kalan 1.000 Akçe ücretleri- (BOA. D.35/50).

26 Haziran 1611/14 Rebîulâhire 1020 Cumartesi

-1020 y1lı Muharrem başından Rebîu'l-âhire sonuna kadar dört ay için 1.200 Akçe Merhum 
İbrahim Paşa vakfı zemini kirası- (BOA. D.35/79).

14 Aralık 1611/8 Şevvâl 1020 Salı

-Masraf- Mütevelli Bevvâb Mehmed Bey zamanında merhum İbrahim Paşa Sarayı vakfı kira bakkalliyesi 1.535 Akçe- (BOA. D.35/94).

29 Mart 1612/26 Muharrem 1021 Perşembe

-1020 Cemâiye'l-âhire başından Zilhicce sonuna kadar 2.400 Akçe inşası devam eden cami-i şerif için İstanbul'daki merhum İbrahim Paşa Vakfi Sarayı zemininin kira küsuru- (BOA. D.35/97).

12 Eylül 1612/16 Receb 1021 Pazartesi

-1021 Muharrem başından Cemâziye'l-âhire sonuna kadar 6 aylık mezbur vakfın mütevelli tezkiresine göre İbrahim Paşa vakfı yıkık sarayının 1800 Akçe kıymete kiralanması- (BOA. D.35/123).

6 Nisan 1613/15 Safer 1022 Cumartesi

-Masraf- Dimo eliyle 5 kıyye 26 Akçe lökün pahası, 1 Şevvâl 1021- 30 Safer 1022 arası cami-i şerif yakınındaki İbrahim Paşa Sarayı vakfı zemîni mukataası kirası 5 aylık 1.500 Akçe(BOA. D.35/128).

-1022 1 Muharrem-20 Safer arası kâtip Mehmed Çelebi defterine göre şakirtleriyle birlikte halîfeler ve neccârlar için 63 nefere 48.983 Akçe ücret-.

21 Mayıs 1613/1 Rebî‘ülâhire 1022 Salı

Masraf -Bevvâb Ali Bey defterine göre At meydanında İbrahim Paşa sarayı yakınında büyük harabelerin 1.716 adet eski moloz taşlarını taşımak için 5.148 Akçe eşekle taşıma ücreti- (BOA. D.35/129).

\section{Ekim 1613/6 Ramazân 1022 Pazar}

-1022 Rebîu'l-evvel başından, Şaban sonuna kadar 6 ay için cami-i şerif yakınındaki merhum İbrahim Paşa ağası vakfı sarayı zemini için 1.800 Akçe kira küsuru- (BOA. D.35/148).

1 Kasım 1614/28 Ramazân 1023 Cumartesi

-Mimar Ağa tezkiresine göre İbrahim Paşa duvarı tamiri için 768 Akçe ustalık ücreti, 40 Akçe suyolu kazısı için temel harcı pahası- (BOA. D.35/180).

-Hamamın önündeki yeni odaların temelinde köşe pâyesi döşeme kaplaması için 3.895 Akçe ücret-.

28 Şubat 1615/29 Muharrem 1024

-1024 Muharrem itibariyle vacip olduğu üzere İbrahim Paşa Sarayı korunması için 4 nefer bostanciya 750 Akçe nafaka-.

28 Nisan 1615/29 Rebî‘ulevvel 1024 Salı

-1024 Rebîu'l-evvel ve Safer'inde İbrahim Paşa Sarayı korunması vaktinde 2 nefer bostanciya 1.500 Akçe nafaka- (BOA. D.35/198).

21 Mayıs 1615/22 Rebî‘ulâhire 1024 Çarşamba

-Îrâd- Dârüssâdeti'ş-şerîfe Ağası ve nâzır Hazret-i Hacı Mustafa Ağa eliyle vezir ve Câmi-i Şerîf Bina Emîni Kalender Paşa'ya 1.760.692 Akçe teslim edildi- (BOA. D.35/201). 
-1024 Rebîu'l-âhire'de vacip olduğu üzere 17 nefer suyolculara 70 gün için 2.100 Akçe, aynı tarihlerde vacip olduğu üzere Hazreti Ebi Eyyup Ensârî sebilcileri 2 nefere 300 Akçe, aynı tarihler itibariyle Memi Miftâhî ve Mustafa Reis'e 540 Akçe nafaka, aynı tarihlerde vacip olduğu üzere bina-i şerifte kenetler çivileri için 6 nefere 1.800 Akçe ücret, aynı tarihler itibariyle Mehmed Paşa Sarayı muhafazası için 4 nefer bostancıya 750 Akçe ücret- (BOA. D.35/202).

\section{Yüzyıl Sonrası İbrahim Paşa Sarayı}

Kronolojinin sunduğu bilgiler çerçevesinde İbrahim Paşa Sarayı'nın birimlerinden Ağustos 1609/1 Cemâziye'l-evvel 1018- 13 Ekim 1617/12 Şevval 1026 tarihleri arasında önce dış duvarlar sonra; at binaları, alt kat ve üst kat odalar, helvahâne, fırın, kiler, kasırlar ve hamam yıkılmıştır. Öyleki zer dûzan olarak ifade edilen altın işlemeli, varaklı odalar da bu yıkımdan nasibini almıştır. Bu aşamada kenifleriyle birlikte bir kasrın yapıldı̆̆ı, aynı dönemde bodrum katları ve zemin odaların atölyeler için kiralanmaya devam edildiği ve hamamın büyütülüp havuzla birlikte tamamlandığı görülür. Buna göre sarayın bodrum kat seviyesindeki atölyelerin kullanılmaya devam edilmesi ve bu kiralama işinin kasır yapılıncaya kadar sürmesi, İbrahim Paşa Sarayı'nın divanhanenin de bulunduğu bölümünde en azından bodrum kat seviyesinde bir değişikliğin olmadığını göstermesi açısından önemlidir. Zaten ikinci avlu içinde birbirine ve meydana açılan beşik tonozlu hücrelerin sarayla doğrudan bir bağlantısı yoktur. Kot farkının bu hücrelerle kapatıldığı saray kasrı, halen altında bulunan hipodrom ve dehliz kalıntılarının üstüne yapılmıştır. Bu kasır için temel seviyesinde bir kazı yapılmayışı, yıkım ve inşa çalışmalarının bodrum kat seviyesinin üstünde devam etmesinden kaynaklanmaktadır.

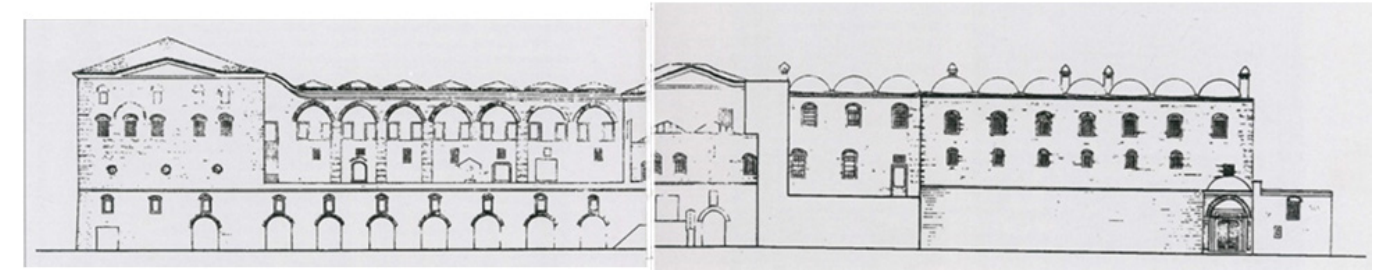

Fig. 4. İbrahim Paşa Sarayı'nın At Meydanı'na bakan cephesinin Y. Mimar Ertuğrul Eğilmez ve Y. Mimar Fatin Uluengin rölövesi (Atasoy 2012, 110)

Kronolojinin verdiği bilgiler dâhilinde mehterhânenin bu inşa faaliyetlerinde hiç yer almayıp At Meydanı'na komşu bir yapı olarak İbrahim Paşa Sarayı hizasında Firuz Ağa Camii’ne yakın bir konumda olduğuna hükmedilebilir. Nitekim Tarih-i Lütfi'de, umumî hapishaneye dönüştürülen mehterhânenin bu tamir süreci 1870/1287 tarihli faaliyet olarak şu şekilde yer almaktadır: " $O$ âna kadar kürek cezâsıyla mahkûm olan erbâb-ı cerâyim Tersâne-i Âmire'de küreğe vaz' olunurdu. Bu husûsun kā'ide-i merhamet ve adâlete tatbîkan icrâsı zımninda, Sultan Ahmed Meydanı'nda vâki' eski mehterhâne ki, mühimmât-ı hiyâmiyeye dâire tahsis olunmuş idi; Mahâll-i mezkûrun tahliyesiyle mebâliğ-i vefîre sarf olunarak, biri mûcrimîne, diğeri nihâyet üç sene kadar habs olunacak mahbuslara mahsûs olmak üzere, iki dâireye bi't-taksîm müte'addîd koğuşlar, hastahâneler ve ehl-i san'at olanlar içün mahâller ile hamam, câmi', kilise ve sâireyi hâvi olarak, pek mükemmel ve muntazam sûrette ta'mîr ve tesviye olunup, hapis-hâne-i umûmî ittihâz kılınmış olan mahâlli, sadr-ı a'zam ile vükelâ bi'l-mu'âyene tahsîn olunmuş ve bunun seyr ü temâşâsi içün istek edenlere, oranın birkaç gün açık bulundurulacağı i'lân kılınmıştır. $O$ tarihden bed' ile mahbusların oraya nakliyle iskânlarına karar verilmiştir" (Lütfi Paşa, Tarih-i Lütfi XII, 100; Öten 2008, 69). 


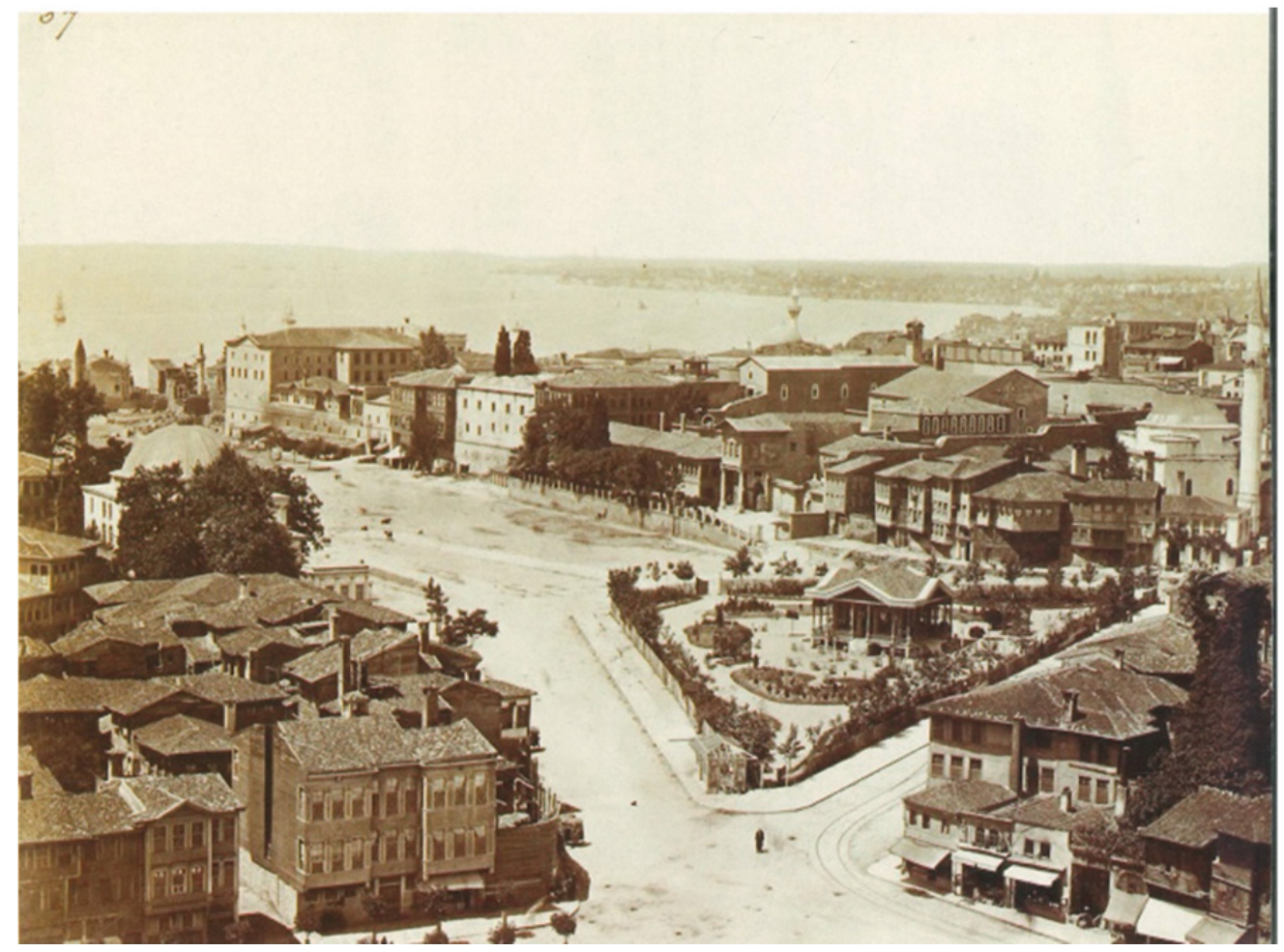

Fig. 5. Sultan Ahmed Meydanı'nda İbrahim Paşa Sarayı ve Hamamının arada elbise deposu ile birlikte görünümü. (Bahattin Öztuncay Arşivi; Atasoy 2012, 193)

Hapishane-i umumi ile ilgili Arkeoloji Müzesi Tarih Encümeni Arşivi'nde fotoğraflar yer almaktadır (Atasoy 1972, 221-222). 1853-1854/1270 tarihli kitâbesiyle eski mehterhâne binas1 olarak tarif edilen bu yerin Firuz Ağa Camii'ne yakın konumlandığı görülmektedir. Kullanılan ifadelerde camii, kilisesi, hamamı, hastahanesi vb. gibi ek yapılarıyla bahsi geçen mehterhâne, İbrahim Paşa Sarayı'nın hamam vb. yapıları ile desteklenmiş olmalıdır. Günümüze ulaşamayan bu yapının kalıntılarının bir kısmı, mevcut müzenin arkasında yer almaktadır. Yeni mehterhâne ise günümüzdeki kullanımıyla Four Season Otel olarak, Dersaadet Cinayet Tevkifhânesi başlıklı ve 1919-1920/1338 tarihli kitâbesiyle Ayasofya'ya yakın bir konumda yer almaktadır.

Sultan Ahmed Meydanı'nda varlığından bahsedilen ve İbrahim Paşa Sarayı ile yakından ilgili yapılardan biri de Defterhâne'dir. 18. yüzyıla kadar Topkapı Sarayı'nda varlığını sürdüren Defterhâne'nin İbrahim Paşa Sarayı'nda tahsis edilen odalarının tamir kaydı mevcuttur (Afyoncu 2014, 14). İbrahim Paşa Sarayı vakfının bir bölümünde yapılan bu faaliyetle sarayın alanı daraltılmıştır. İbrahim Paşa Sarayı'nın ne zaman Defterhane olduğu bilinmemekle birlikte daha 1755 öncesinde bir bölümünün Defterhane olarak kullanılmaya başlanmış olması mümkündür (Eyice 2000, 345-347). Tarih-i Lütfi'de yer alan 1845/1262 tarihli kayıtta ise hazîne-i evrakın inşasından bahsedilmektedir. Bu faaliyette Sultan Ahmed'de At Meydanı nezdinde Defter-i Hakânî'nin bulunduğu ve doğal sebeplerle zarar gören evrakların Fossati'nin yaptığı Evrak Hazinesi'ne taşındığından da bahsedilmektedir (Lütfi Paşa, Tarih-i Lütfi XIII, 120; Öten 2008, 42). 1881'den itibaren çeşitli müdahaleler ile mehterhâne ve mehterhâne kasrı da katılarak Defter-i Hakânî Nezareti'ne dönüştürülen bu yapı, 20. yüzyıl başında Tapu ve Kadastro Müdürlüğü olarak hizmet verecek şekilde yeniden inşa edilmiştir. 


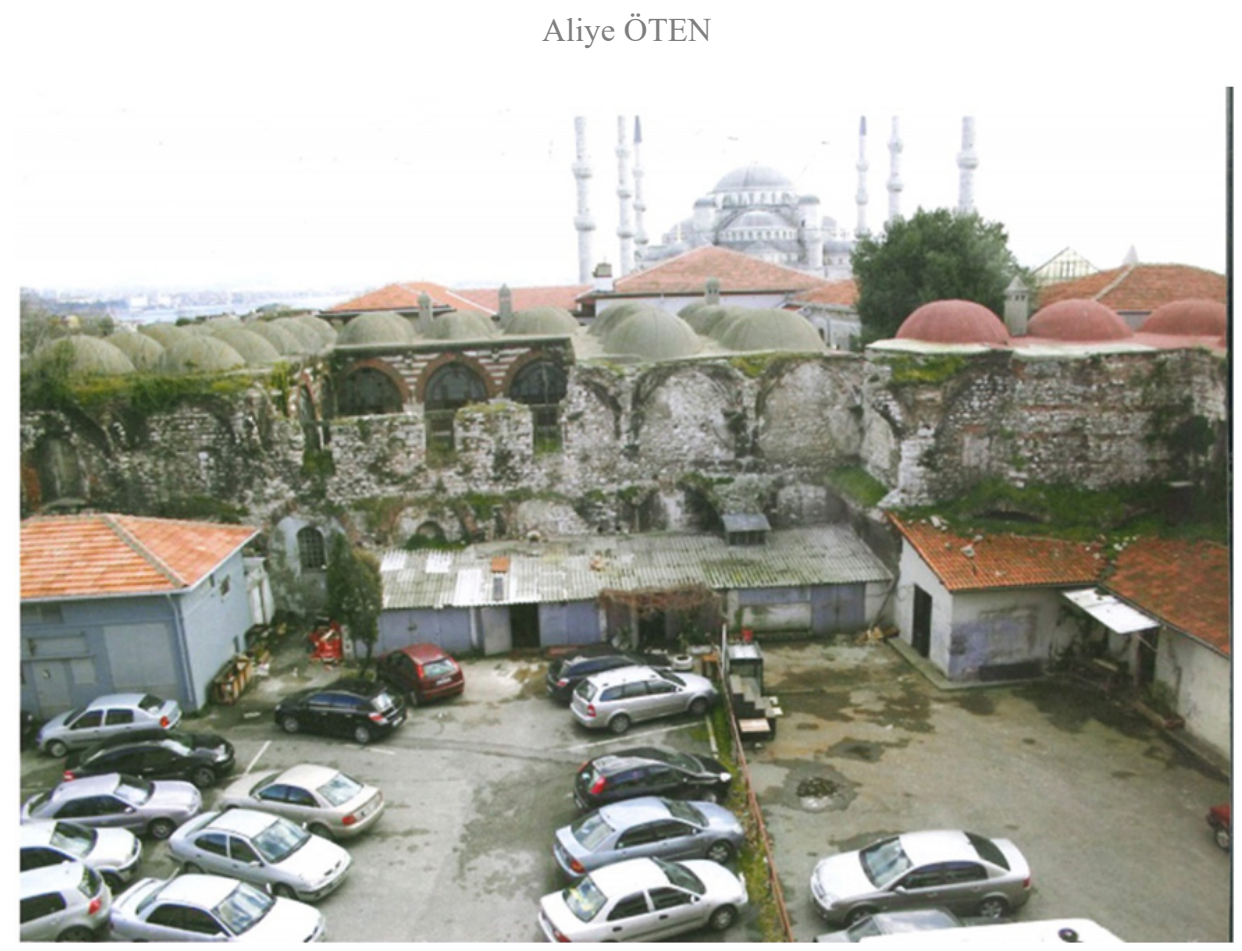

Fig. 6. İbrahim Paşa Sarayı Hamamı ve Hapishane-i umumi kalıntıları (Atasoy 2012, 195)

At Meydanı'na bakan yapıların bir kısmı 1939'a kadar cezaevi olarak kullanılıyor, bir kısmı ise orduya ait bulunuyordu. Meydanda yeni bir adliye sarayının yapılmasının uygun görülmesi üzerine bunun için eski binaların yıkılması kararlaştırıldığında eski yapıların kimliği tartışma konusu olmuştur. İbrahim Paşa Sarayı, mehterhâne, defterhane vs. net bir şekilde ayrılamadığ halde yıkım başlamış ve adliye sarayı inşa edilmiştir. İbrahim Paşa Sarayı'ndan, arkadaki sahada mahalle içinde sadece bazı şekilsiz duvar parçaları ile bir hamam harabesi kalmıştır (Eyice 2000, 345-347).

Bugünkü kalıntılarından anlaşıldığı kadarıyla, müstahkem görünüşlü olan saray, geleneksel Osmanlı mekân organizasyonunu yansıtmaktaydı. At Meydanı cephesi $140 \mathrm{~m}$. olarak kalmış ve dört avlu etrafina yerleştirilmiş sarayın bugün Tapu ve Kadastro Dairesi'nin arkasında kalan birinci avlusu bir cephesiyle At Meydanı'na açılmaktaydı. Avlunun iki yan cephesinde yer alan kapılarla sarayın ikinci ve üçüncü avlularına geçiliyordu. Yine meydana paralel uzanan üçüncü cephenin bir yanında ise günümüze gelemeyen bir rampa ile ulaşılan yalnız padişahın ata binerek geçebileceği asıl girişi bulunuyordu. Bu giriş kronoloji'de de belirtildiği üzere Sultan Ahmed Han'ın külliye ziyaretlerini kolaylaştırmak için yapılan yolla birlikte Sultan Ahmed Külliyesi inşasında ele alınmış olmalıdır (BOA. D. 35/22).

Bu avlunun sağındaki kapının yanında Defter-i Hakânî Emini Server Dede'nin türbesi vardı. Sarayın çöküş ve parçalanış sürecinde önce defterhane binası bu avluda inşa edilmişti. Daha sonra da Tapu ve Kadastro Dairesi'ne bağlanan sarayın bu bölümü özgün yapısını kaybetmiş bulunmaktaydı. İkinci avlu sarayın ilk inşasından geriye kalan tek avludur ve esas olarak Türk ve İslam Eserleri Müzesi'nin büyük iç avlusuna denk düşmektedir. Birinci avludan daha yüksek seviyede olan bu mekâna (İbrahim Paşa Sarayı'nın ön cephesindeki padişahın seyir köşkü) bir dizi merdiven ve kapıdan geçilerek ulaşılmaktadır. İkinci avlu minyatürlerde, padişahın görüldüğü balkonun sağında onun gösterileri rahatça izleyebileceği, ancak dışarıdan içerisinin görünmemesini sağlayacak ahşap kafesli bir seyirliğin arkasına isabet eden ağaçlıklı bir alan olarak resmedilmektedir. 


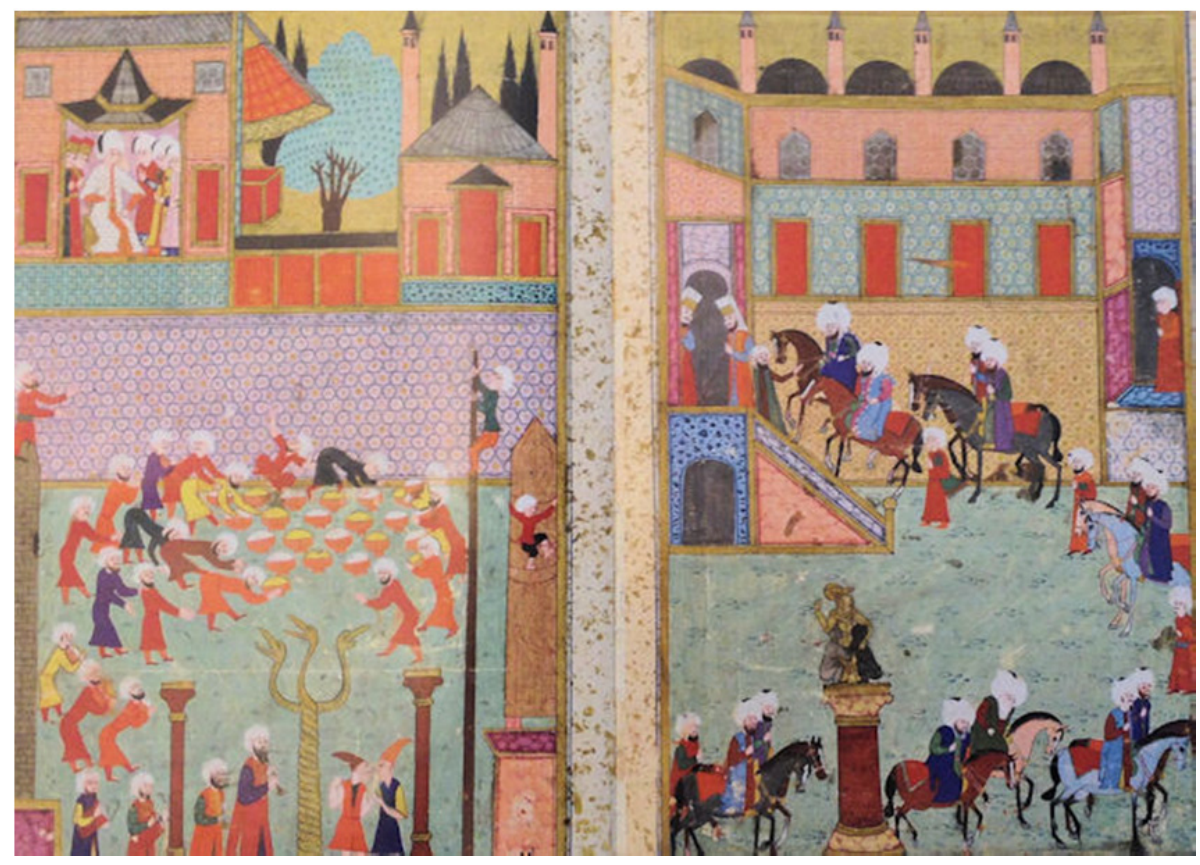

Fig. 7. Seyyid Lokman'ın Surname minyatürlerinde At Meydanı'nda sünnet şenlikleri ve İbrahim Paşa Sarayı'nın padişahın atına mahsus rampasıyla girişi (TSMH, 1344/326-327)

Sarayla meydan arasındaki seviye farkı sebebiyle ikinci avlunun meydana bakan doğu cephesi bir istinat galerisi üzerine oturtulmuştur. Bu istinat galerisi, beşik tonozlu kemerlerle birbirine ve meydana açılan mekânlardan oluşur. Meydan cephesinde sarayla bağlantısı olmayan bodrum katları, sarayın yeniden yapılışı ve Sultan Ahmed Külliyesi inşa sürecinde dükkân ve atölye olarak kullanılmıştır. İkinci avlunun zemin katında güney, batı ve kuzey cephelerini birbirine açılan koğuşlar biçiminde tonozlu mekânlar çevirir. Bu mekânları avluya ve bugün arkada yıkılmış olan sarayın diğer bölümlerine bağlayan kapılar bulunmaktadır.

Halen girişin üzerinde yer alan köşk, minyatürlerde resmedilen ve muhtemelen padişah dıșındaki hanedan üyelerinin törenleri seyrettiği köșk olarak restorasyona dâhil edilmiş olmalıdır ancak; Sultan Ahmed Külliyesi inşa planında yer alan ve destarlı korkulukları ile şakirdan için tamamlandığı bildirilen 17. yüzyıl kasır yapısı olması da imkân dâhilindedir. Bugün burada görülen mimari elemanların zaman içinde birçok değişikliğe maruz kaldığ düşünülecek olursa; restorasyona alınacak kısımların seçiminde hangi dönemin ele alınacağı da ayrı bir paradoks oluşturmakta ve ortaya çıkacak sonucun orijinalliği her daim tartışma konusu olmaktadir.

İkinci avlunun batı ve kuzey yönünde ikinci katta bulunan mekânlar da batıda tonoz, kuzeyde kubbelerle örtülmüştür. İçlerinde ocakların mevcut olduğu bu mekânların önünde kubbeli bir revak yer almaktadır. Sultan Ahmed Han'ın At Meydanı'na geldiğinde inşa sahası ve külliye bütününü seyrettiği yer sarayın ve ikinci avlunun güneyindeki divanhanedir. Bu bölümün birçok kaynakta "kasır, köşk, taht" olarak söz edilen bölüm olduğuna hükmedilebilir. Son restorasyonlarda yeniden inşa edilmiştir. Avluya bakan cephesi harap vaziyette yakın zamana kadar gelmiş, ancak duvara gömülü kırmızı sütun izleri bulunduğundan kırmızı boyalı ahşap kemerlerle birbirine bağlı ahşap sütunlarla çevrili olacak biçimde restore edilmiştir. Divanhânenin ardında bir kapıyla geçilen kışlık divanhane ya da iç divanhane yer almaktadır. 


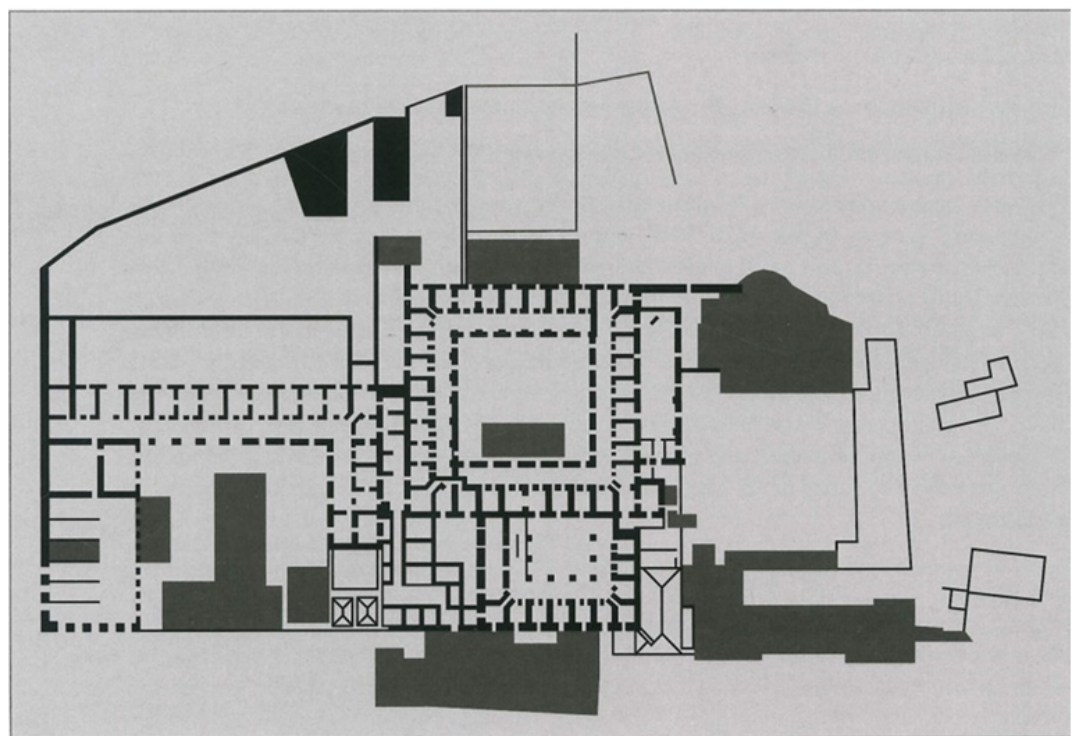

Fig. 8. İbrahim Paşa Sarayı'nın yeniden yapımından önce 1939'da Sedat Çetintaş tarafından çizilmiş planı (Atasoy 2012, 110)

Kışl1k divanhanenin güney cephesinde görülen bir kapı ise burada ek bir bina olduğunu düşündürmektedir. Ana cepheye dik gelen sarayın kuzey cephesinin bir bölümünü oluşturan üçüncü avlu sarayın en küçük avlusuydu. Üç cephesini, alt katta avlu kenarlarına dik İbrahim Paşa Sarayı ve önündeki At Meydanı'nı tasvir eden bir minyatür (Hünername, TSMK, 1524/250) beşik tonozlardan oluşan koğuşlar, üst katta eşit büyüklükteki kubbeli odalar ve önlerinde revaklar çeviriyordu. Üçüncü avlunun dördüncü (batı) cephesi ise sarayın dördüncü avlusunun bulunduğu bölüme bitişikti. Günümüzde bu avlunun yerinde Adalet Sarayı Arşiv Dairesi yer almaktadır. Üçüncü avlunun arka cephesine bitişik olan dördüncü avlu 1939'da Adliye Sarayı'na yer açmak için tamamen yıkılmıştır.

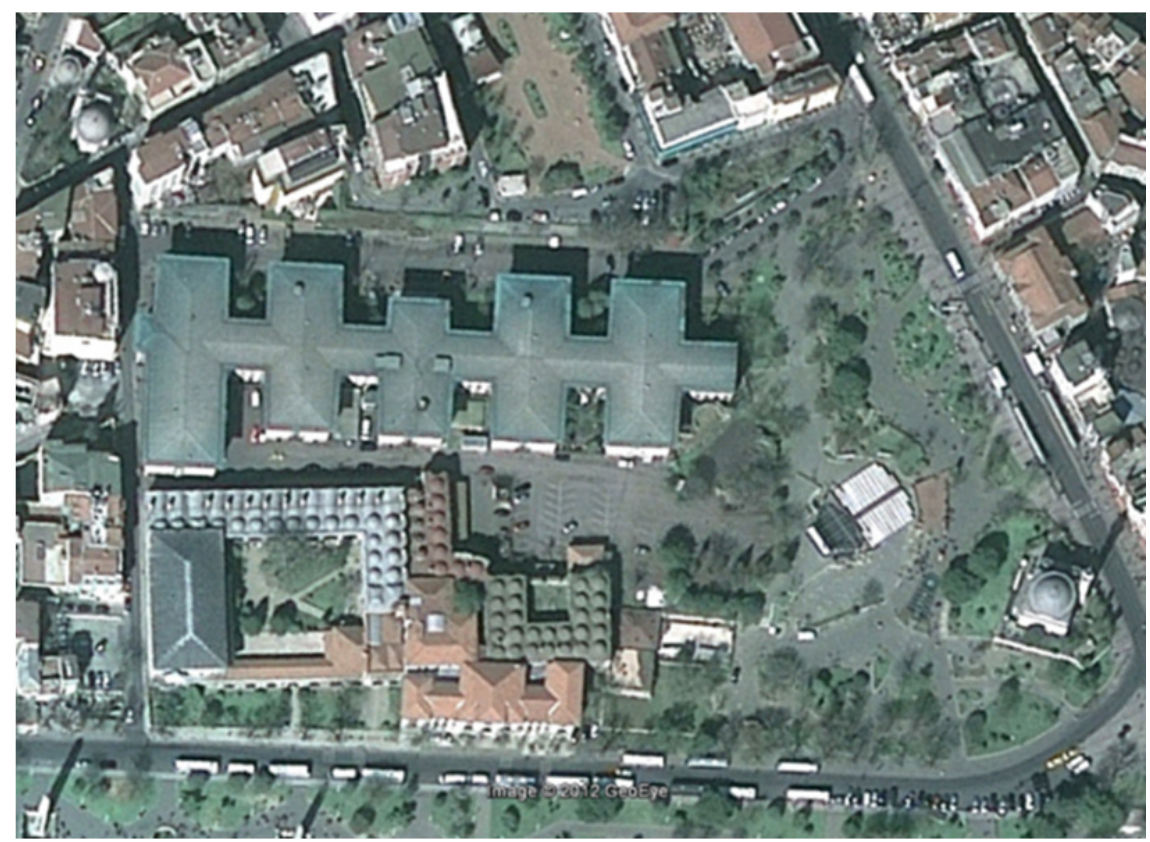

Fig. 9. Eski Adliye Binası, bugünkü İstanbul İl Milli Eğitim Müdürlüğü ve İbrahim Paşa Sarayı ile ilişkisini gösteren uydu fotoğrafı (http://www.kalinti-istanbul.com/item/eski-adliye-binasi/) 
Yıkım öncesi yapılan mimari çizimlerle fotoğraflardan, dördüncü avlunun da eşit büyüklükteki kubbeli odalar ve önlerinde revaklarla çevrili olduğu anlaşılmaktadır. Dârü'l-fünûn Binası'nın yanmasının ardından yeni bir adliye binasına gereksinim duyulunca yeni bina için yer tartışmaları başlamıştır. Yeni adliyenin İbrahim Paşa Sarayı yıkılarak onun yerine yapılması dahi düşünülmüş ve büyük tartışmalara sebep olmuştur. Ardından bugün otel olarak kullanılan Sultan Ahmed Cezaevi'nin yıkılarak yeni binanın oraya yapılması fikri baskın çıkmış ama her nedense bundan da vazgeçilerek bugünkü yerinde karar kılınmıştır. Binanın yeri kesinleşince 1939 yılında gerekli istimlâkler yapılmış ve İbrahim Paşa Sarayı'nın kısmi yıkımına başlanmıştır. Bu kapsamda sarayın meydana göre arka tarafinda kalan dördüncü avlusu tamamen yıkılmıştır. II. Dünya Savaşı'nın araya girmesiyle çalışmalar yarım kalmıştır. Savaştan sonra, 1949 yılında yapılan proje yarışmasını kazanan Sedat Hakkı Eldem ve Ord. Prof. Emin Halid Onat'ın projesinin inşasına 1951 yılında başlanmış ve Adliye Binası 1955 yılında hizmete açılmıştır. Adliye Binası'nın inşası sadece İbrahim Paşa Sarayı'na zarar vermemiş, Roma Hipodromu'nun Batı cephesinden kalan son izleri de yok etmiştir.

Sarayın iç mekân kullanımına dair çok sağlıklı bilgi yoktur. Ancak Osmanlı saraylarının genel mekân organizasyonu temel alınarak bazı tespitlerde bulunmak, hazine, mutfak, hamam, hela ve ahır gibi mekânları yerleştirmek mümkün olabilmektedir.
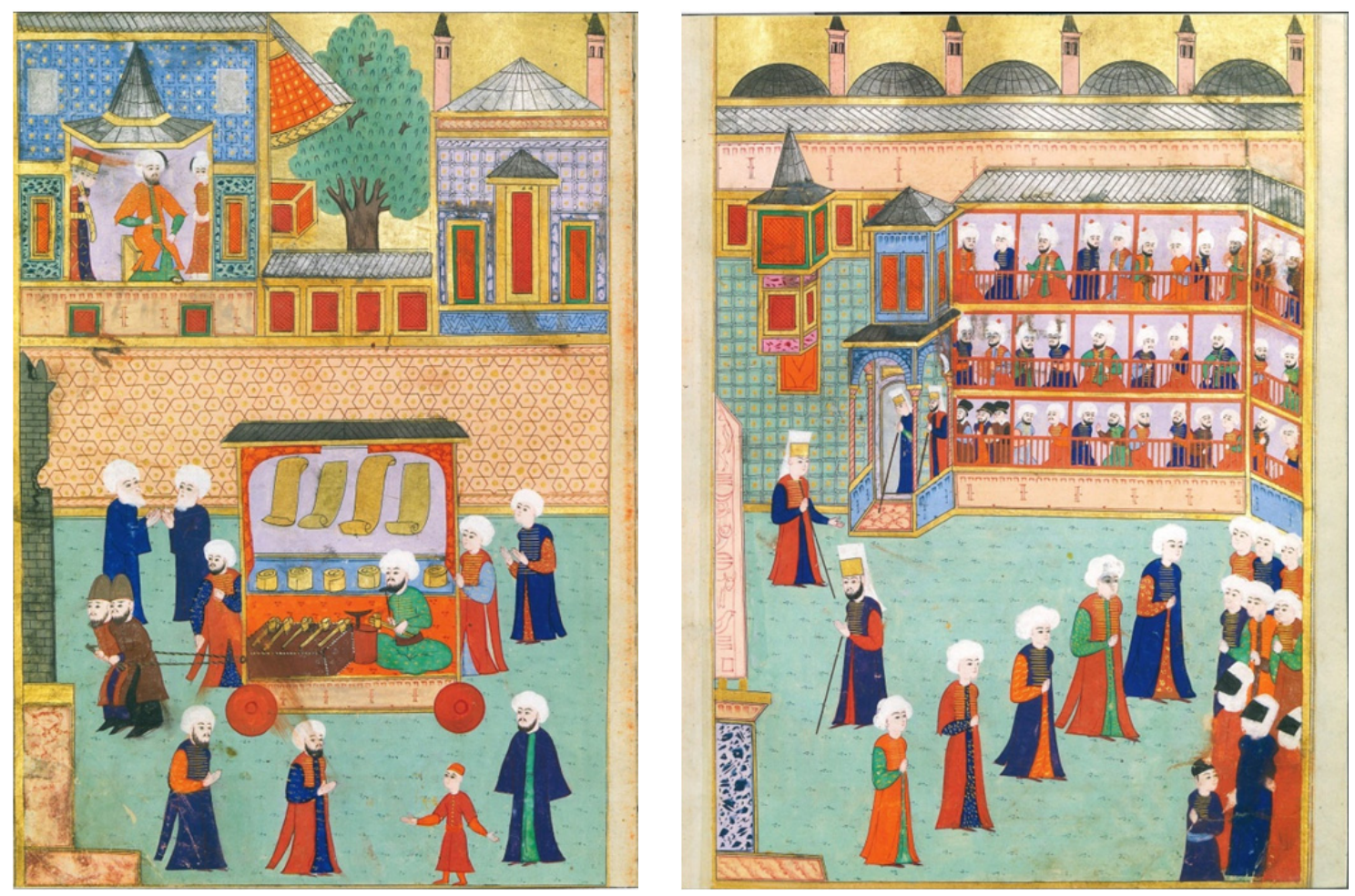

Fig. 10-11. Şehzade Mehmed'in sünnet düğününü anlatan Surname minyatürlerinde At meydanı ve İbrahim Paşa Sarayı (TSMH, 1344/326-327)

Meydana açılan bir kapıdan girilen saray arka arkaya iki iç avluya sahip bulunuyordu. XVI. yüzyıla ait Surname minyatürlerinde de kasrın meydana bakan cephesi görülür (Levnî Surname, TSMH 1344, 326-327). XV1ll. ve XIX. yüzyıllarda Batılı ressamlar tarafindan Sultan Ahmed Meydanı'nın resimleri yapıldığında, Sultan Ahmed Camii karşısında belirtilen kuleli ve ön cephesinin altında revak olan yapının İbrahim Paşa Sarayı ile ilgisi pek anlaşılamamıştır. Meydanın bir kenarında Adliye Sarayı ile meydan arasında kalan alanı kaplayan büyük yapı topluluğunun içinde saraydan kalan parçaların bulunup bulunmadığ 1 tespite muhtaçtır. Firuz 
Ağa Camii tarafındaki kısımların sarayla bir ilgileri olmadığı kesin olmakla beraber aksi taraftaki bina bloğunun içinde saraydan kalmış parçaların bulunması mümkündür. Son yıllarda Üçler sokağına komşu olan tarafin tamirine başlanmış ve burasının Türk ve İslam Eserleri Müzesi'nin bir bölümü olarak kullanılmak üzere gerekli projeleri hazırlanmıştır. Büyük çalışmalar sonunda mimar Hüsrev Tayla (1984) idaresinde mevcut eski yapılar ayıklanarak bazı bölümler ihya edilmiş ve burası Türk ve İslam Eserleri Müzesi olarak düzenlenmiştir.

\section{Sonuç}

İbrahim Paşa Sarayı, ilk evraklardan anlaşıldığı üzere 16. yüzyıl başında inşa edilmiş ve yüzyıl içerisinde bünyesinde yapılan değişiklerle şehrin meydanına (At Meydanı) hâkim bir yapı haline gelmiştir. Adıyla anılan Makbûl İbrahim Paşa'ya intikal eden, vefatından sonra da pek çok kez el değiştiren sarayın ilk mimarı bilinmese de; şenlikler için giriş ve seyir alanları hazırlanması gibi değişiklerde tarih itibariyle Mimar Sinan'ın dahli olduğu düşünülebilir.

Sarayın 16. yüzyıldaki hali ile ilgili bilgi ve belgeler sınırlıdır. Bu dönemdeki haline örnek olarak verilebilecek tasvirler ise, plan ve cephe tasarımını yansıtmakta eksiktir. Çünkü minyatür sanatında da, tüm sanatlarda olduğu gibi sanatçının gözlemi ve kişisel bakış açısı da esere yansımaktadır. Sanatçı fenomenlerle farklı bir ilişki kurarak eserini meydana getirir. Önemli gördüğü yerleri vurgulayabilir. Bu durumda esas yapı hakkında genel geçer bir bilgi edinmekle birlikte; hacim, ebat, muhteviyat ile ilgili bilgilerimiz sınırlı kalmaktadır. Buna göre Matrakçı Nasuh'un İstanbul minyatüründe kuzey cephesinden görülen yapılar topluluğunda, revaklı ve şahnışinli iki bölümüyle yüksek ve büyükçe bir yapı (divanhâne olması muhtemel) dikkat çekmektedir (Matrakçı Nasuh Beyân-1 Menâzil-i Sefer-i Irakeyn, İ. Ü. Ktp. T.5964, 8). Bu yapının iki yanında küçük kubbeli yapılar mevcuttur. Hepsinin önünde revaklı ve örtüsü kırma çatılı fevkani bir bölüm bulunmaktadır. Bu bölümün yanında kule benzeri bir yapı, onun da sağında farklı seviyelerde yükseklikleriyle çatılı ve pencereli binalar görülmektedir. Sarayın At meydanına bakan cephesi hakkında ise net bir bilgi yoktur.

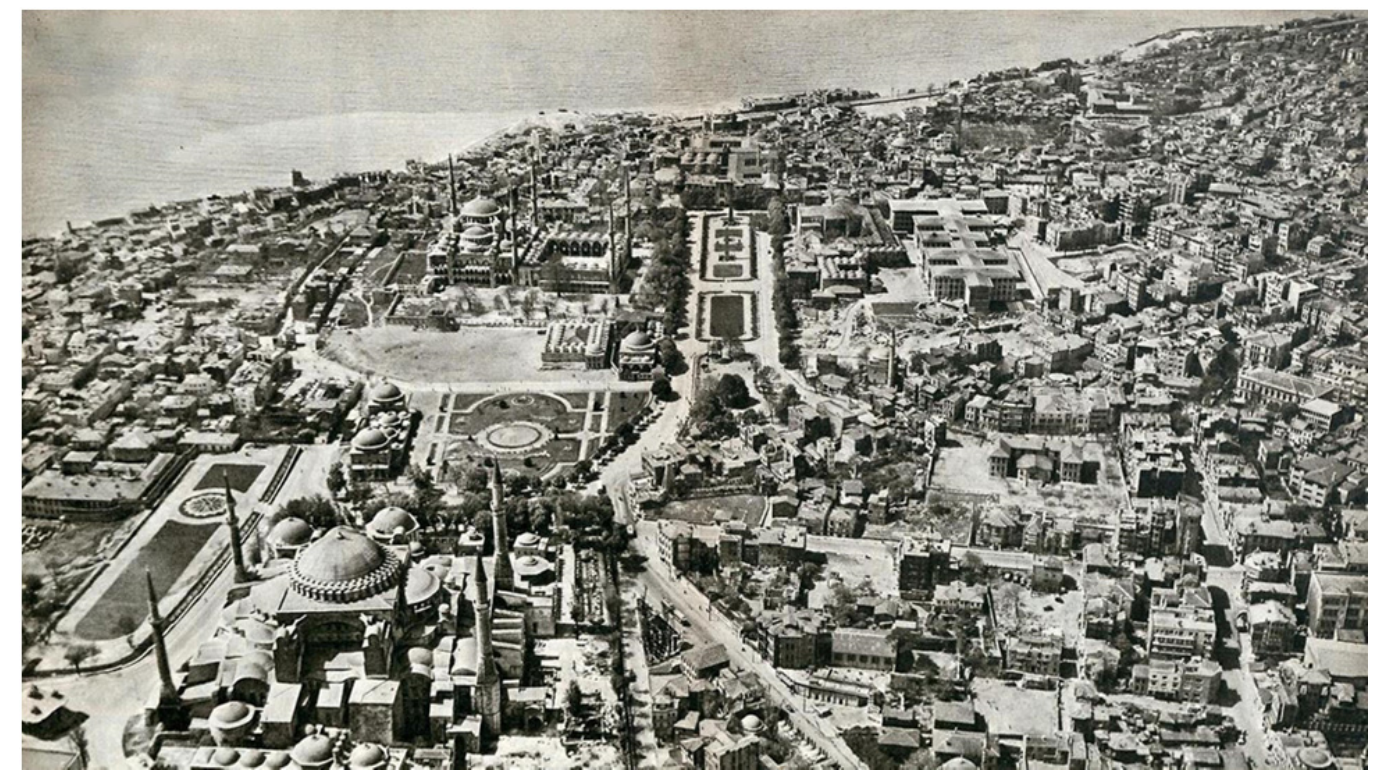

Fig. 12. 1967 Sultan Ahmed Meydan1 (http://eistinpolin330.blogspot.com/2013/07/)

İbrahim Paşa Sarayı'nın 17. yüzyıl daki konumu ise tamamen farklıdır. Sultan Ahmed Külliyesi inşasında temlik kayıtlarına göre Sultan Ahmed tarafından satın alınan ve At Meydanı çevresindeki diğer yapılarla birlikte Sedefkâr Mehmed Ağa tarafından yeniden inşa edilen saray, yıkılan 
ve yeniden yapılan bölümleriyle bambaşka bir hüviyete bürünmüştür. Bu faaliyetin Sultan Ahmed Külliyesi inşasında şantiyeyi sık sık ziyaret edip, çok geniş bir müdahale alanıyla meydanı şekillendiren bânî Sultan Ahmed Han için gerçekleştiği kayıtlardan anlaşılmaktadır. 17. yüzyıl başında cereyan eden bu imar faaliyeti sonucunda; sarayın adı İbrahim Paşa Sarayı vakfı olarak değiştiği gibi kulanım amacı, plan ve cephe tasarımı da değişmiştir. Ayrıca sarayın hamamı genişletilmiş ve havuz da eklenmiştir. Hamamının yenilenmesi ve sarayın vakıf olarak adlandırılması da sünnet vb. büyük şenliklere hazırlık kabilinden olup meydana damgasını vuran ve adını veren Sultan Ahmed Han'ın bu konudaki öngörüsü ve titiz takibinin bir sonucudur.

Bugün yerlerini tam tanımlamakta zorluk çektiğimiz sanayi mektebi, defterhane ve mehterhâne gibi yapılarla ilişkisi, sarayın bugünkü durumunu ve en azından 20. yüzyıl başında girişilen restorasyon faaliyetini tanımlamak için gereklidir. Ancak, sürekli değişen ve saray alanına müdahale eden yapılar kadar; yangın, deprem vb. doğal afetler nedeniyle de bu durum zorlaşmaktadır. Aradan geçen dört yüzyıllık bir süreçte çokça değişim geçiren saray, kalıntılardan yola çıkılarak yapılan rölövelerle son (17. yüzyıl) görünümü esas alınarak yeniden gün yüzüne çıkarılmıştır. Bu faaliyetle ilgili bilgilerin henüz gün yüzüne çıkmasıyla İbrahim Paşa Sarayı'nın daha önceki durumu ile ilgili yapılan tahminler hükmünü yitirmektedir.

Ayrıca sarayın 16. yüzyıldaki tasvirleriyle 17. yüzyıl ve sonrasindaki tasvirlerini mukayese etmek sarayın yıkılıp yeniden yapıldığı bilgisiyle daha anlaml olacaktır. Buna göre 17. yüzyıl ve sonraki sünnet şenliklerini konu alan tasvirlerde; hamam yapısı önündeki padişaha ve diğer seyircilere tahsis edilmiş seyir terasları, alt katını taş ihata duvarlarının oluşturduğu divanhanenin iki yönde şahnışinli yapısı dikkat çeker. Aynı duvarların biraz daha solunda iki bacalı ve yüksek katlı çatılı bir bina da mevcuttur. Bu tariflerden de anlaşılacağı üzere bu tasvirlerde sarayın kuzey cephesi görülmemektedir. Ayrıca yapıları aynı cepheden karşılaştırma imkâ$\mathrm{n} 1$ da bulunmamaktadır. Bu da daha genel bilgilere ulaşmayı mümkün kılmamaktadır.

Mimar Sedat Çetintaş'ın Sultan I. Ahmed zamanında yenilenen sarayın kalıntılarından yola çıkarak hazırladı ̆̆ plan-

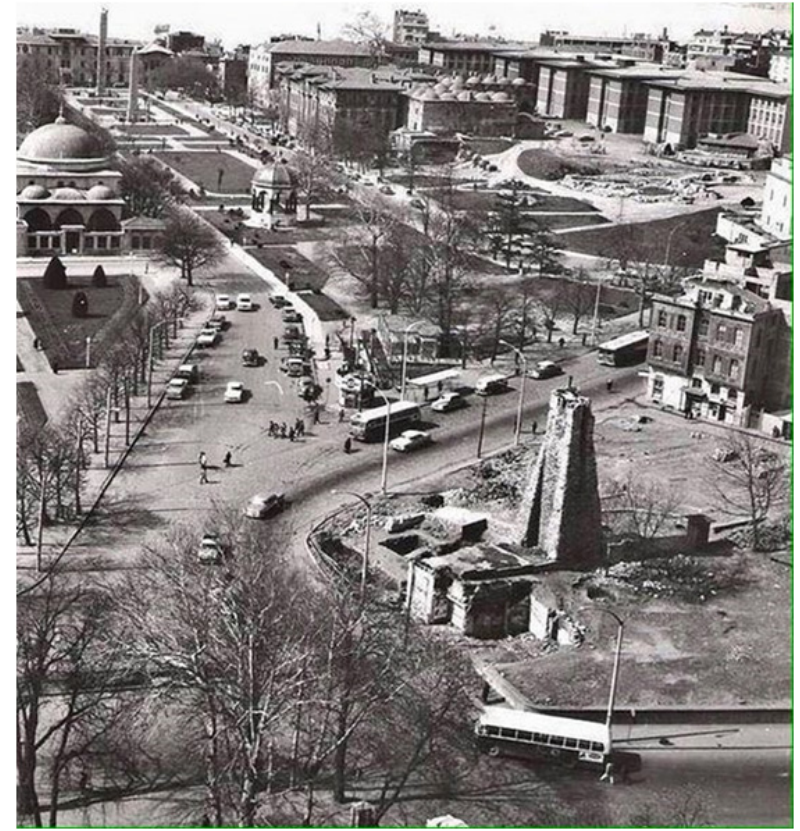

Fig. 13. 1970'lerde Sultan Ahmed Meydanı (Alman Arkeoloji Enstitüsü Kütüphanesi Arşivi) larıyla 1970'lerde yeniden canlandırılan saray, bugün Türk ve İslam Eserleri Müzesi olarak hizmet vermeye devam etmektedir.

Yazarın notu: $\mathrm{Bu}$ çalışma, Arşiv Belgelerine Göre Sultan Ahmet Külliyesi ve İnşası adlı doktora tezinin bir bölümü olarak çalışılmıştır. 


\section{KAYNAKÇA}

Atasoy N. (2012). İbrahim Paşa Sarayı. İstanbul 2012.

Efendi A. H., Efendi A. S. \& Efendi S. B. (2001). Hadîkatü'l- Cevâmi' (İstanbul Câmileri ve Diğer DînîSivil Mi'mârî Yapılar). İstanbul 2001.

Bilge M. L. (2013). "Sultanahmed Cami ve Külliyesi: Kuruluş Öncesi ve Sonrası Belgeler". Osmanlı $\dot{I}_{s-}$ tanbul'u I: I. Uluslararası Osmanlı İstanbul'u Sempozyumu Bildirileri (2013) 525-557.

Cantay T. (1988). “Atmeydanı”. Türkiye Diyanet Vakfi İslam Ansiklopedisi (Cilt 1) 82. İstanbul 1988.

Çelebi Evliya. (2013). Seyahatname. Çev. Y. Dağlı \& S. A. Kahraman. İstanbul 2013.

Çelebi Sai (1988). Tezkiretü'l-bünyan. İstanbul 1988.

Çetintaş S. (1939). Saray ve Kervansaraylarımız Arasında İbrahim Paşa Sarayı. İstanbul 1939.

Çürük C. (1993). "Çadır Mehterleri”. Türkiye Diyanet Vakfi İslam Ansiklopedisi (Cilt 8) 165. İstanbul 1993.

Efendi A. Lütfî. (1290). Tarih-i Devlet-i Aliyye-i Osmani. İstanbul 1290.

Emecen F. (2000). “İbrahim Paşa, Makbûl”. Türkiye Diyanet Vakfi İslam Ansiklopedisi (Cilt 21) 333-335. İstanbul 2000.

Eyice S. (2000). “İbrahim Paşa Sarayı”. Türkiye Diyanet Vakfi İslam Ansiklopedisi (Cilt 11) 345-347. İstanbul 2000.

Gurlitt C. (1999). İstanbul'un Mimari Sanatı. Çev. R. Kızıltan. İstanbul 1993.

Konyalı İ. H. (1942). İstanbul Sarayları. İstanbul 1942.

Lokman Seyyid (n.d.). Hünername. TSMK, Hazine, nr. 1524.

Nasuh Matrakçı (n.d.). Beyân-ı Menâzil-i Sefer-i Irakeyn. İstanbul Üniversitesi Kütüphanesi T.5964

Öten A. (2008). Ahmet Lütfi Paşa Tarihi'nde İmar ve İnşâ Faaliyetleri. Yayımlanmamış Yüksek Lisans Tezi. Marmara Üniversitesi, İstanbul 2008.

Özcan N. (2003). "Mehter”. Türkiye Diyanet Vakfi İslam Ansiklopedisi (Cilt 28) 547-549. İstanbul 2003.

Sahillioğlu H. (1993). "Ceyb-i Hümâyûn”. Türkiye Diyanet Vakfi İslam Ansiklopedisi (Cilt 7) 465-467. İstanbul 1993.

Tayla H. (1984). “İbrahim Paşa Sarayı Restorasyon Raporu”. Mimaride Türk Milli Üslubu Semineri (1984) 100.

Ünver A. S. (1938). “İbrahim Paşa Sarayı Hakkında Birkaç Resim ve Minyatür”. Arkitekt 8 (1938) 5-6.

\section{Arşiv Belgeleri}

Başbakanlık Osmanlı Arşivi (BOA):

BOA, D.35, 1609-1616.

BOA, D.10748.0001.00, 1610.

BOA, D.00211.0001.00, 1617.

Topkapı Sarayı Müzesi Arşivi (TSMA):

TSMA. D.9621, TSMA D.10748, TSMA. E.7624, TSMA. 250 